\title{
Sodium hexatitanate photocatalysts prepared by a flux method for reduction of carbon dioxide with water
}

\section{$\operatorname{AUTHOR}(\mathrm{S})$ :}

Yoshida, Hisao; Sato, Masumi; Fukuo, Naoto; Zhang, Like; Yoshida, Tomoko; Yamamoto, Yuta; Morikawa, Takeshi; ... Sekito, Takeshi; Matsumoto, Shinichi; Hirata, Hirohito

\section{CITATION:}

Yoshida, Hisao ...[et al]. Sodium hexatitanate photocatalysts prepared by a flux method for reduction of carbon dioxide with water. Catalysis Today 2018, 303: 296-304

\section{ISSUE DATE:}

2018-04-01

URL:

http://hdl.handle.net/2433/250239

\section{RIGHT:}

(c) 2017. This manuscript version is made available under the CC-BY-NC-ND 4.0 license http://creativecommons.org/licenses/by-nc-nd/4.0/:; この論文は出版社版でありません 。引用の際には出版社版をご確認ご利用ください。; This is not the published version. Please cite only the published version. 


\section{Sodium hexatitanate photocatalysts prepared by a flux method for}

\section{reduction of carbon dioxide with water}

Hisao Yoshida, ${ }^{\mathrm{a}, \mathrm{b}, \mathrm{c}, *}$ Masumi Sato, ${ }^{\mathrm{a}}$ Naoto Fukuo, ${ }^{\mathrm{a}}$ Like Zhang, ${ }^{\mathrm{c}}$ Tomoko Yoshida, ${ }^{\mathrm{d}, \mathrm{e}}$ Yuta Yamamoto, ${ }^{\mathrm{e}}$

Takeshi Morikawa, ${ }^{\mathrm{f}}$ Tsutomu Kajino, ${ }^{\mathrm{f}}$ Mitsuru Sakano, ${ }^{\mathrm{g}}$ Takeshi Sekito, ${ }^{\mathrm{g}}$ Shinichi Matsumoto ${ }^{\mathrm{g}}$ and

Hirohito Hirata ${ }^{\mathrm{g}}$

\footnotetext{
${ }^{a}$ Graduate School of Human and Environmental Studies, Kyoto University, Kyoto 606-8501, Japan

${ }^{b}$ Elements Strategy Initiative for Catalysts and Batteries (ESICB), Kyoto University, Kyoto 615-8520, Japan

${ }^{c}$ Graduate School of Engineering, Nagoya University, Nagoya 464-8603, Japan

${ }^{d}$ Advanced Research Institute for Natural Science and Technology, Osaka City University, Osaka 558-8585, Japan.

${ }^{e}$ EcoTopia Science Institute, Nagoya University, Nagoya 464-8603, Japan

${ }^{f}$ Toyota Central R\&D Labs., Inc., Nagakute, Aichi 480-1192, Japan

${ }^{g}$ Toyota Motor Corporation, Toyota 471-8572, Japan

* To whom correspondence should be addressed. E-mail: yoshida.hisao.2a@kyoto-u.ac.jp
}

*Corresponding author:

Hisao Yoshida, Professor, Dr.

Course of Studies on Material Science

Department of Interdisciplinary Environment

Graduate School of Human and Environmental Studies

Kyoto University

Yoshida-nihonmatsu-cho, Sakyo-ku, Kyoto 606-8501, JAPAN

Phone: $+81-75-753-6594$

FAX: $\quad+81-75-753-2988$

E-mail: yoshida.hisao.2a@kyoto-u.ac.jp 


\begin{abstract}
Flux method was applied to prepare sodium hexatitanate $\left(\mathrm{Na}_{2} \mathrm{Ti}_{6} \mathrm{O}_{13}\right)$ photocatalysts for reduction of carbon dioxide with water. The preparation conditions were examined, such as the starting material, the flux, the composition in the molten mixture, the holding temperature, and the cooling rate of the molten mixture, so as to obtain several sodium hexatitanate samples consisting of the crystals with various morphologies and sizes. These samples were loaded with $0.1 \mathrm{wt} \%$ of $\mathrm{Ag}$ cocatalyst nanoparticles $\left(\mathrm{Ag} / \mathrm{Na}_{2} \mathrm{Ti}_{6} \mathrm{O}_{13}\right)$ and examined for photocatalytic reduction of carbon dioxide with water, where carbon monoxide, hydrogen and oxygen were formed as products. It was found that the photocatalytic production rate of carbon monoxide varied with the morphology and the size of the sodium hexatitanate crystals. Among the prepared samples, thick rod-like crystals exhibited high photocatalytic activity for the reduction of carbon dioxide.
\end{abstract}

Keywords: Heterogeneous photocatalyst; $\mathrm{CO}_{2}$ reduction; Artificial photosynthesis; Flux method. 


\section{Introduction}

An increasing concentration of atmospheric carbon dioxide $\left(\mathrm{CO}_{2}\right)$, which should originate from large consumption of fossil fuels, has been considered as the most responsible reason for the current climate change [1]. Since the activity of the photosynthesis in leaf for $\mathrm{CO}_{2}$ fixation on the earth is limited, artificial photosynthesis producing valuable compounds from $\mathrm{CO}_{2}$ by utilizing solar energy has been much attractive in view of reducing the $\mathrm{CO}_{2}$ emission, recycling $\mathrm{CO}_{2}$ as a carbon source and converting solar energy to the chemical potential of the products [2-8].

Heterogeneous photocatalysis has been studied for the reduction of $\mathrm{CO}_{2}$ with water to produce formate, carbon monoxide (CO), methanol and methane [9-15]. Especially, in recent years, many kinds of $\mathrm{Cu}$ or $\mathrm{Ag}$ modified photocatalysts to produce $\mathrm{CO}$, hydrogen $\left(\mathrm{H}_{2}\right)$ and oxygen $\left(\mathrm{O}_{2}\right)$ have been reported, such as $\mathrm{Cu} / \mathrm{ZrO} \mathrm{O}_{2}$ [16], $\mathrm{Ag} / \mathrm{BaLa}_{4} \mathrm{Ti}_{4} \mathrm{O}_{15}$ [17], $\mathrm{Ag} / \mathrm{Ga}_{2} \mathrm{O}_{3}$ [18-21], $\mathrm{Ag} / \mathrm{Zn}-\mathrm{Ga}_{2} \mathrm{O}_{3}$ [22], $\mathrm{Ag} / \mathrm{KCaSrTa}_{5} \mathrm{O}_{15}$ [23], $\mathrm{Ag} / \mathrm{La}_{2} \mathrm{Ti}_{2} \mathrm{O}_{7}$ [24], and $\mathrm{Ag} / \mathrm{CaTiO}_{3}[25,26]$. In these systems, two reactions competitively proceed, i.e., photocatalytic reduction of $\mathrm{CO}_{2}$ to form $\mathrm{CO}$ and $\mathrm{O}_{2}$ (eq. 1) and photocatalytic water splitting into $\mathrm{H}_{2}$ and $\mathrm{O}_{2}$ (eq. 2).

$$
\begin{aligned}
& \mathrm{CO}_{2} \rightarrow \mathrm{CO}+1 / 2 \mathrm{O}_{2} \\
& \mathrm{H}_{2} \mathrm{O} \rightarrow \mathrm{H}_{2}+1 / 2 \mathrm{O}_{2}
\end{aligned}
$$

The reaction selectivity between the two reactions varies with the employed photocatalyst. On the surface of the photocatalyst, both reduction of $\mathrm{CO}_{2}$ and proton by the excited electrons (eq. 3 and 4 ) and oxidation of water into $\mathrm{O}_{2}$ and proton (eq. 5) can occur.

$$
\begin{aligned}
& \mathrm{CO}_{2}+2 \mathrm{H}^{+}+2 \mathrm{e}^{-} \rightarrow \mathrm{CO}+\mathrm{H}_{2} \mathrm{O} \\
& 2 \mathrm{H}^{+}+2 \mathrm{e}^{-} \rightarrow \mathrm{H}_{2} \\
& 2 \mathrm{H}_{2} \mathrm{O}+4 \mathrm{~h}^{+} \rightarrow \mathrm{O}_{2}+4 \mathrm{H}^{+}
\end{aligned}
$$

In these photocatalytic systems, however, the enough production rates have not been achieved yet for the practical use. Thus, a clear guidance for catalyst design has been required for further development. 
In some systems, it is reported that the morphological structure of the photocatalyst affects the photocatalytic activity for the $\mathrm{CO}_{2}$ reduction. For example, on the $\mathrm{Ag} / \mathrm{BaLa}_{4} \mathrm{Ti}_{4} \mathrm{O}_{15}$ photocatalyst of anisotropic plate-like structure [17], the reduction of $\mathrm{CO}_{2}$ to produce $\mathrm{CO}$ can take place on the Ag cocatalyst at the edges of the plates while the oxidation can progress on the $\mathrm{BaLa}_{4} \mathrm{Ti}_{4} \mathrm{O}_{15}$ surfaces. In other words, it can be recognized that the separated reaction fields for reduction and oxidation would contribute to the high photocatalytic performance. In our previous study [25], we prepared several $\mathrm{Ag} / \mathrm{CaTiO}$ shotocatalyst samples, where a clear relationship was revealed between the particle size of polyhedral $\mathrm{CaTiO}_{3}$ crystals in micro meter scale and the photocatalytic production rate of $\mathrm{CO}$, i.e., the larger size of crystal provided higher activity for the production of $\mathrm{CO}$.

Flux method employed in the previous and the present studies can provide fine single crystals or poly crystals and thus has been applied to fabricate various micro or nano-sized photocatalysts in recent years. For example, many kinds of titanate photocatalysts were reported such as $\mathrm{Na}_{2} \mathrm{Ti}_{6} \mathrm{O}_{13}$ [27], $\mathrm{Na}_{2} \mathrm{Ti}_{3} \mathrm{O}_{7}$ [28], $\mathrm{K}_{2} \mathrm{Ti}_{6} \mathrm{O}_{13}$ [29,30], $\mathrm{CaTiO}_{3}[25,26], \mathrm{SrTiO}_{3}$ [31], $\mathrm{La}_{2} \mathrm{Ti}_{2} \mathrm{O}_{7}$ [32,33], $\mathrm{PbTiO}_{3}$ [34], $\mathrm{CaZrTi}_{2} \mathrm{O}_{7}$ [35] and $\operatorname{AgLi}_{1 / 3} \operatorname{Ti}_{2 / 3} \mathrm{O}_{2}[36]$.

In the present study, we prepared several $\mathrm{Ag} / \mathrm{Na}_{2} \mathrm{Ti}_{6} \mathrm{O}_{13}$ photocatalyst samples by using a flux method. The $\mathrm{Na}_{2} \mathrm{Ti}_{6} \mathrm{O}_{13}$ semiconductor has a unique tunnel structure [27] and has a bandgap (3.5 eV) [37] larger than that of anatase $\mathrm{TiO}_{2}(3.2 \mathrm{eV})$ and rather closed to that of $\mathrm{CaTiO}_{3}(3.6 \mathrm{eV})[25,38]$. Thus, it is expected to be also active for the photocatalytic reduction of $\mathrm{CO}_{2}$. Actually in the present study, it was found that the $\mathrm{Ag} / \mathrm{Na}_{2} \mathrm{Ti}_{6} \mathrm{O}_{13}$ photocatalyst can promote the photocatalytic reduction of $\mathrm{CO}_{2}$ to $\mathrm{CO}$. In addition, a good relationship was revealed between the structure and the photocatalytic activity.

\section{Experimental}

\subsection{Sample preparation}

Most of the $\mathrm{Na}_{2} \mathrm{Ti}_{6} \mathrm{O}_{13}$ samples in the present study were synthesized by a flux method in the same manner described our previous works $[25,26,30]$ from $\mathrm{Na}_{2} \mathrm{CO}_{3}$ (Rare metallic, 99.9\%, melting point is $1124 \mathrm{~K}$ ) and $\mathrm{TiO}_{2}$ (rutile, Kojundo, $99.9 \%, 2 \mu \mathrm{m}$, melting point is $2116 \mathrm{~K}$ ) as start materials by using some chlorides such as $\mathrm{LiCl}, \mathrm{NaCl}, \mathrm{KCl}$ and $\mathrm{CaCl}_{2}$ as a flux (the melting points are 878, 1074, 1043 and $1045 \mathrm{~K}$, respectively). The molar ratio of $\mathrm{Na}_{2} \mathrm{CO}_{3}$ to $\mathrm{TiO}_{2}$ was $1: 6$, and various ratios of the substrate $\left(x\right.$ mol\% as $\left.\mathrm{Na}_{2} \mathrm{Ti}_{6} \mathrm{O}_{13}\right)$ in the mixture with the flux were examined, where $x$ was defined as: $x$ [mol\%] $=100 \times\left(\right.$ amount of $\mathrm{Na}_{2} \mathrm{Ti}_{6} \mathrm{O}_{13}$ 
[mol]) / (amount of $\mathrm{Na}_{2} \mathrm{Ti}_{6} \mathrm{O}_{13}[\mathrm{~mol}]+$ amount of a flux [mol]). The mixture of starting materials was put into a platinum crucible, which was loosely covered by a lid, heated at a rate of $200 \mathrm{~K} \mathrm{~h}^{-1}$ to 973,1073 or $1273 \mathrm{~K}$ (standard: $1273 \mathrm{~K}$ ) in an electric furnace, held at this temperature for $10 \mathrm{~h}$, and then slowly cooled at a rate of $-100,-10$ or $-5 \mathrm{~K} \mathrm{~h}^{-1}$ (standard: $-100 \mathrm{~K} \mathrm{~h}^{-1}$ ) to $773 \mathrm{~K}$, followed by being naturally cooled to room temperature in the furnace. It is considered that the decarbonation of $\mathrm{Na}_{2} \mathrm{CO}_{3}$ would take place to form $\mathrm{Na}_{2} \mathrm{O}$ species during heating, the mixture of the starting materials would be molten, and then both melted $\mathrm{Na}_{2} \mathrm{O}$ and melted $\mathrm{TiO}_{2}$ would react with each other to form $\mathrm{Na}_{2} \mathrm{Ti}_{6} \mathrm{O}_{13}$ crystallites in the molten salt during the cooling step. The obtained products were well washed with hot water $(353 \mathrm{~K})$ three times to remove the flux. These samples are referred to as $\mathrm{NTO}(f l u x, x$, note if any), e.g., $\mathrm{NTO}(\mathrm{NaCl}, 50), \mathrm{NTO}(\mathrm{NaCl}, 5,1073 \mathrm{~K})$, $\mathrm{NTO}\left(\mathrm{NaCl}, 50,-10 \mathrm{Kh}^{-1}\right)$ and so on.

One sample was prepared by a solid state reaction method (SS method). The same starting materials, $\mathrm{Na}_{2} \mathrm{CO}_{3}(0.03 \mathrm{~mol})$ and $\mathrm{TiO}_{2}$ (rutile, $\left.0.18 \mathrm{~mol}\right)$, were dried at $373 \mathrm{~K}$, mechanically mixed by a wet ballmilling method with $150 \mathrm{~g}$ of alumina balls and $80 \mathrm{~mL}$ of acetone in a plastic bottle $(300 \mathrm{~mL})$ for $24 \mathrm{~h}$ at $120 \mathrm{rpm}$, dried in an oven at $353 \mathrm{~K}$ overnight, and heated in air atmosphere at $1273 \mathrm{~K}$ for $10 \mathrm{~h}$ in an alumina crucible in the furnace. The sample is referred to as NTO(SS). Another sample was prepared by the flux method with anatase $\mathrm{TiO}_{2}$ supplied by Catalysis Society of Japan, JRC-TIO-8 $\left(338 \mathrm{~m}^{2} \mathrm{~g}^{-1}\right)$ as the start material, i.e., $\mathrm{NTO}(\mathrm{NaCl}, 50$, anatase $)$.

Ag cocatalyst was loaded on the surface of the $\mathrm{Na}_{2} \mathrm{Ti}_{6} \mathrm{O}_{13}$ samples by a photodeposition method, where $\mathrm{AgNO}_{3}$ and methanol (25 vol.\%) was used as the Ag source and the reductant, respectively. The loading amount of $\mathrm{Ag}$ as metal was $0.1 \mathrm{wt} \%$. The samples are referred to as $\mathrm{Ag} / \mathrm{NTO}$, e.g., $\mathrm{Ag} / \mathrm{NTO}(\mathrm{NaCl}, 50)$.

\subsection{Characterizations}

Several kinds of analyses were employed to characterize the prepared samples, such as XRD, XRF, ICP, SEM, TEM, DR UV-vis, BET, DTA, pHzPC, and XAFS, the details of which are mentioned in the Electric Supplementary Information (ESI).

\subsection{Photocatalytic reaction tests}

Photocatalytic reaction tests were carried out under ambient temperature and pressure in the same manner as the previous study [25]. The details are described in the ESI. Detected products were $\mathrm{CO}, \mathrm{H}_{2}$, and $\mathrm{O}_{2}$. 
Other products were not observed in this system even in the liquid phase after the reaction, although the possibility of the formation of undetected byproducts was not denied especially in the liquid phase. In the present study, the selectivity to $\mathrm{CO}$ in the reduced products was defined as follows: $\mathrm{S}_{\mathrm{CO}}(\%)=100 \times($ the production rate of $\mathrm{CO}$ ) / ( sum of the production rates of $\mathrm{CO}$ and $\mathrm{H}_{2}$ ).

\section{Results and discussion}

\subsection{Preparation with various fluxes}

Since molten salt as a flux can regulate the crystal growth to provide unique morphology of the crystals in many cases, some kinds of the salts such as $\mathrm{LiCl}, \mathrm{NaCl}, \mathrm{KCl}$, and $\mathrm{CaCl}_{2}$ were examined for the preparation of $\mathrm{Na}_{2} \mathrm{Ti}_{6} \mathrm{O}_{13}$ samples. Fig. 1 shows XRD patterns of the obtained samples with that from database [39] as a reference and that of the rutile $\mathrm{TiO}_{2}$ sample used as the start material. Among them, the $\mathrm{NTO}(\mathrm{NaCl}, 50)$ sample, the $\mathrm{NTO}(\mathrm{KCl}, 50)$ sample and the $\mathrm{NTO}(\mathrm{SS})$ sample (Fig. 1b, 1c, and 1e) exhibited almost the same pattern to that of the reference data (Fig. 1f), indicating that $\mathrm{Na}_{2} \mathrm{Ti}_{6} \mathrm{O}_{13}$ crystallites of monoclinic structure were obtained. It is noted that the distribution of the diffraction line intensity of the NTO samples prepared by the flux method are different from that of the $\mathrm{NTO}(\mathrm{SS})$ sample and the reference, for example, the intensity of the line at $24.5^{\circ}$ corresponding to (110) plane was relatively low for the former patterns and high for the latter patterns, implying that the $\mathrm{Na}_{2} \mathrm{Ti}_{6} \mathrm{O}_{13}$ crystals prepared by the flux method have an anisotropic morphology. Although the $\mathrm{NTO}(\mathrm{NaCl}, 50)$ sample and the $\mathrm{NTO}(\mathrm{KCl}, 50)$ sample exhibited almost similar diffraction patterns, the latter showed a small shift to lower angle. XRF measurement revealed that the $\mathrm{NTO}(\mathrm{KCl}, 50)$ sample contained small amount of potassium and the composition of the sample was estimated to be $\mathrm{Na}_{1.46} \mathrm{~K}_{0.54} \mathrm{Ti}_{6} \mathrm{O}_{13}$, where potassium cation having the larger size than sodium cation would enlarge the lattice constant.

The NTO(LiCl,50) sample showed a quite different pattern than others (Fig. 1a). By using XRF and ICP, the composition of this sample was estimated to be $\mathrm{Li}_{1.17} \mathrm{Na}_{1.40} \mathrm{Ti}_{6} \mathrm{O}_{14.2}$, indicating that pure phase of sodium hexatitanate $\left(\mathrm{Na}_{2} \mathrm{Ti}_{6} \mathrm{O}_{13}\right)$ was not obtained. It is also revealed that the $\mathrm{NTO}\left(\mathrm{CaCl}_{2}, 50\right)$ sample was a mixture of $\mathrm{TiO}_{2}$ (major) and $\mathrm{CaTiO}_{3}$ (minor) (Fig. 1d). These facts indicate that both $\mathrm{LiCl}$ and $\mathrm{CaCl}_{2}$ salts are not suitable for the preparation of $\mathrm{Na}_{2} \mathrm{Ti}_{6} \mathrm{O}_{13}$ crystals. 
The XRF measurement revealed that these samples did not contain a detectable amount of $\mathrm{Cl}$ anions, meaning that the removal of the flux was almost completed by washing with hot water.

SEM images elucidated various morphologies of these NTO samples prepared with various fluxes in the flux method and without any flux in the SS method (Fig. 2). The $\mathrm{NTO}(\mathrm{LiCl}, 50)$ sample consisted of large particles (Fig. 2a), the $\mathrm{NTO}(\mathrm{NaCl}, 50)$ and $\mathrm{NTO}(\mathrm{KCl}, 50)$ samples showed rod-like morphology (Fig. $2 \mathrm{~b}$ and 2c), the $\mathrm{NTO}\left(\mathrm{CaCl}_{2}, 50\right)$ sample exhibited particles covered with small fragments (Fig. 2d), and the $\mathrm{NTO}(\mathrm{SS})$ sample showed ununiformed particles (Fig. 2e). In some cases, various facets could be observed on the surfaces of the particles prepared by the flux method (Fig. 2, a-c). It was clarified that both the use of flux and the property of the flux much affected the shape of the particles. This confirms that the molten salt can regulate the crystal growth of each facet to form the unique morphology and this effect depends on the property of the cation such as $\mathrm{Li}^{+}, \mathrm{Na}^{+}, \mathrm{K}^{+}$and $\mathrm{Ca}^{2+}$. Among them, it is remarkable that the two $\mathrm{Na}_{2} \mathrm{Ti}_{6} \mathrm{O}_{13}$ samples prepared by the flux method, i.e., the $\mathrm{NTO}(\mathrm{NaCl}, 50)$ sample and the $\mathrm{NTO}(\mathrm{KCl}, 50)$ sample, exhibited rod-like crystals. They were similar to the reported ones in the literatures for $\mathrm{Na}_{2} \mathrm{Ti}_{6} \mathrm{O}_{13}$ [27] and $\mathrm{K}_{2} \mathrm{Ti}_{6} \mathrm{O}_{13}$ [30], where the cross-section of the rod-like structure was typically hexagonal. In the present samples some steps were also observed. On the other hand, the $\mathrm{NTO}(\mathrm{SS})$ sample of the $\mathrm{Na}_{2} \mathrm{Ti}_{6} \mathrm{O}_{13} \mathrm{structure}$ prepared by the SS method showed granular polyhedral particles connected to each other.

As a conclusion in this section, it is noted that the $\mathrm{NaCl}$ flux is suitable for the preparation of the pure phase of the hexagonal rod-like $\mathrm{Na}_{2} \mathrm{Ti}_{6} \mathrm{O}_{13}$ crystals.

\subsection{Preparation with $\mathrm{NaCl}$ flux with various conditions}

Some samples were prepared by using the $\mathrm{NaCl}$ flux with various solute concentrations in the standard condition. Fig. 3 shows their SEM images. It was elucidated that these samples prepared by the flux method consisted of similar hexagonal rod-like crystals and both the size and the aspect ratio varied with the solute concentration $x$ in the molten mixture. The lowest solute concentration (5\%) provided the clear shape of the fine rod-like crystals (Fig. 3a), while the highest (70\%) gave somewhat irregular shape (Fig. 3c). The sizes of the crystals were evaluated from the SEM images and listed in Table 1, entries $1-4$. The NTO(NaCl,5) sample consisted of the longest rod-like crystals of $6.4 \mathrm{~nm}$ in length on the average. The average length clearly decreased with an increase of the solute concentration $x$ in the molten mixture among the samples prepared by the flux method. On the other hand, the average width of them once increased with an increase 
of $x$ to the maximum, i.e., $1.1 \mathrm{~nm}$ at $x=50$, then decreased. The aspect ratio of the crystals in these samples decreased from 8.7 to 2.6 with an increase of $x$, and for the sample prepared by the SS method it was 1.3 , almost close to unity (Table 1 , entry 5 ).

Fig. 4 shows a representative TEM image of the $\mathrm{NTO}(\mathrm{NaCl}, 50)$ sample with an electron diffraction pattern. A rod-like particle was obviously found. It is noticed that more transparent perimeter can be observed in the rectangular image of the rod-like crystal, supporting the hexagonal cross-section. When the electron diffraction pattern was monitored at several points of the rod-like crystal, the clear and regular pattern of bright spots was observed for each location (Fig. 4, inset). This fact evidenced that the rod-like crystal was a single crystal.

Fig. 5 shows representative DR UV-visible spectra, which give information for the electronic band structure. The $\mathrm{NTO}(\mathrm{NaCl}, 50)$ sample showed a wide absorption band less than $370 \mathrm{~nm}$ in wavelength, indicating that the estimated bandgap was $3.58 \mathrm{eV}$. This value was very slightly smaller than $3.62 \mathrm{eV}$ for the $\mathrm{NTO}(\mathrm{NaCl}, 5)$ sample and $3.61 \mathrm{eV}$ for the $\mathrm{NTO}(\mathrm{SS})$ sample. This fact might be related to the average width of the rod-like crystals, i.e., the thick crystals gave the smaller bandgap. However, no drastic difference on the electronic band structure was observed from each other. The NTO(SS) sample exhibited an additional small band at 360-400 nm, suggesting the presence of very small amount of unreacted titanium oxide that could not detected by XRD in this sample or some kinds of crystal defects.

The $\mathrm{NTO}(\mathrm{NaCl}, 5,973 \mathrm{~K})$ sample and the $\mathrm{NTO}(\mathrm{NaCl}, 5,1073 \mathrm{~K})$ sample were prepared with lower holding temperatures, 973 and $1073 \mathrm{~K}$, respectively. These temperatures are lower than or almost equal to the melting point of pure $\mathrm{NaCl}(1074 \mathrm{~K})$. XRD profile (not shown) of the former indicated that the holding at $973 \mathrm{~K}$ gave a mixture of rutile $\mathrm{TiO}_{2}$ and $\mathrm{Na}_{2} \mathrm{Ti}_{6} \mathrm{O}_{13}$ phases. The SEM image of this sample (Fig. S1a) also shows the mixture of roundish particles and needle-like crystals, assignable to $\mathrm{TiO}_{2}$ and $\mathrm{Na}_{2} \mathrm{Ti}_{6} \mathrm{O}_{13}$ phases, respectively. The sizes of the needle-like crystals were very small as listed in Table 1 , entry 6 . On the other hand, the holding at $1073 \mathrm{~K}$ was sufficient for providing a pure $\mathrm{Na}_{2} \mathrm{Ti}_{6} \mathrm{O}_{13}$ crystals (XRD was not shown). The SEM images shown in Fig. S1b clarified that the rod-like crystals were formed. The average length and width of the rod-like crystals in this sample were 6.2 and $0.33 \mathrm{~nm}$, respectively as listed in Table 1 , entry 7 , which were smaller than those for the $\mathrm{NTO}(\mathrm{NaCl}, 5)$ sample prepared at $1273 \mathrm{~K}$ (Table 1, entry 1). The variation coefficients for the length and width were $42 \%$ and $28 \%$ for the sample prepared at $1073 \mathrm{~K}$ and $46 \%$ and $40 \%$ for the sample prepared at $1273 \mathrm{~K}$. These facts indicate that the lower temperature provided 
smaller rod-like crystals with narrower size distribution. It is considered that the higher holding temperature would provide enough time for crystal growth in the molten mixture at the longer cooling step.

The cooling rate was also one of the most important parameters controlling the structure of the rod-like $\mathrm{Na}_{2} \mathrm{Ti}_{6} \mathrm{O}_{13}$ crystals. Fig. 6 shows $\mathrm{SEM}$ images of the $\mathrm{NTO}\left(\mathrm{NaCl}, 50,-y \mathrm{Kh}^{-1}\right)$ samples prepared with various cooling rate, $-100,-10$ and $-5 \mathrm{~K} \mathrm{~h}^{-1}$, from $1273 \mathrm{~K}$ to $773 \mathrm{~K}$. As shown, the slow cooling rate such as -10 and $-5 \mathrm{~K} \mathrm{~h}^{-1}$ provided the thicker rod-like crystals than the fast cooling rate as $-100 \mathrm{~K} \mathrm{~h}^{-1}$. The sizes estimated from several SEM images were listed in Table 1 entries 3, 8 and 9. The slow cooling rate would enhance the crystal growth according to Ostwald ripening. The size distribution of the $\mathrm{NTO}\left(\mathrm{NaCl}, 50,-5 \mathrm{Kh}^{-1}\right)$ sample seems to become larger with the slow cooling (Fig. 6c), which was supported by the high variation coefficients, $62 \%$ and $57 \%$, for the length and width of the thick rod-like crystals, respectively.

The structure of the start material also influenced the morphology. When anatase $\mathrm{TiO}_{2}$ powder with high specific surface area $\left(338 \mathrm{~m}^{2} \mathrm{~g}^{-1}\right)$ was employed as the start material instead of rutile powder with low specific surface area $\left(2.5 \mathrm{~m}^{2} \mathrm{~g}^{-1}\right)$, the obtained $\mathrm{NTO}(\mathrm{NaCl}, 50$, anatase $)$ sample consisted of smaller size of rod-like crystals (Fig. S2a, and Table 1, entry 10). In the present study, however, it was not clarified which factor contributed to the smaller size, the anatase structure or the high surface area of the start $\mathrm{TiO}_{2}$ material. The detailed discussion was described in the ESI.

In this study, it was also confirmed that the composition of sodium titanate can be determined by the molar ratio of the two starting materials, $\mathrm{Na}_{2} \mathrm{CO}_{3}$ and $\mathrm{TiO}_{2}$. In other words, the $\mathrm{NaCl}$ flux usually could not react with $\mathrm{TiO}_{2}$ to form sodium titanate in the present condition. For example, when a mixture of $\mathrm{Na}_{2} \mathrm{CO}_{3}$ and $\mathrm{TiO}_{2}$ with the ratio of $1: 3$ was melted in the $\mathrm{NaCl}$ flux and followed by cooling in the same manner, a sample of $\mathrm{Na}_{2} \mathrm{Ti}_{3} \mathrm{O}_{7}$ phase was obtained. When a mixture of only the $\mathrm{NaCl}$ flux and rutile $\mathrm{TiO}_{2}$ powder was examined for the preparation, most of $\mathrm{TiO}_{2}$ remained and some kinds of sodium titanates were formed as minor products, which was confirmed by the XRD (not shown). In this case, a part of $\mathrm{NaCl}$ would be oxidized with the atmospheric $\mathrm{O}_{2}$ to form $\mathrm{Na}_{2} \mathrm{O}$ species in the molten mixture and it would react with $\mathrm{TiO}_{2}$ to form sodium titanates.

In this section, it was confirmed that well controlled thick hexagonal rod-like $\mathrm{Na}_{2} \mathrm{Ti}_{6} \mathrm{O}_{13}$ crystals were obtained when the sample was prepared from rutile $\mathrm{TiO}_{2}$ by using moderate amount of $\mathrm{NaCl}$ flux through high holding temperature at $1273 \mathrm{~K}$ and the moderately slow cooling rate of $-10 \mathrm{~K} \mathrm{~h}^{-1}$. 


\subsection{Deposition of the Ag cocatalyst nanoparticles.}

Silver nanoparticles were deposited as a cocatalyst on these prepared $\mathrm{Na}_{2} \mathrm{Ti}_{6} \mathrm{O}_{13}$ samples by the photodeposition method. Ag loading amount was $0.1 \mathrm{wt} \%$ for each sample. Fig. 7 shows DR UV-visible spectra of the representative Ag loaded samples. The Characteristic bands in the visible light region assignable to the surface plasmon resonance (SPR) of the Ag nanoparticles confirmed the deposition of the Ag cocatalyst. The peak position of the SPR band for the $\mathrm{Ag} / \mathrm{NTO}(\mathrm{NaCl}, 5)$ and $\mathrm{Ag} / \mathrm{NTO}(\mathrm{NaCl}, 50)$ sample was at $500 \mathrm{~nm}$ in wavelength while the $\mathrm{Ag} / \mathrm{NTO}(\mathrm{NaCl}, 70)$ sample exhibited it at $530 \mathrm{~nm}$. This suggests that the Ag nanoparticles deposited on the $\mathrm{Ag} / \mathrm{NTO}(\mathrm{NaCl}, 70)$ sample would be larger than those on the other samples. In the photodeposition method, it is considered that adsorbed Ag ions on the surface of the $\mathrm{Na}_{2} \mathrm{Ti}_{6} \mathrm{O}_{13}$ crystals are reduced by the photoexcited electron generated in the $\mathrm{Na}_{2} \mathrm{Ti}_{6} \mathrm{O}_{13}$ crystals. Thus, the structure of the $\mathrm{Na}_{2} \mathrm{Ti}_{6} \mathrm{O}_{13}$ crystals would affect the photocatalytic property and vary the size of the deposited Ag nanoparticles.

\subsection{Photocatalytic activity}

The prepared $\mathrm{Ag} / \mathrm{Na}_{2} \mathrm{Ti}_{6} \mathrm{O}_{13}$ samples were examined for the photocatalytic reduction of $\mathrm{CO}_{2}$ by water. The products observed in the present study were carbon monoxide $(\mathrm{CO})$, hydrogen $\left(\mathrm{H}_{2}\right)$, and oxygen $\left(\mathrm{O}_{2}\right)$, which consisted with the results in our previous study [25,26] and other reports [16-24]. In these systems including the present one, the reduction of $\mathrm{CO}_{2}$ and water splitting would take place competitively as mentioned above.

In the representative time course of the production rate in the photocatalytic reaction with the $\mathrm{Ag} / \mathrm{NTO}(\mathrm{NaCl}, 50)$ sample (Fig. S3), the production rates for $\mathrm{H}_{2}$ and $\mathrm{CO}$ were initially high, but gradually decreased, and finally became almost constant after a long time passing around $24 \mathrm{~h}$.

Although $\mathrm{O}_{2}$ was not observed initially, it was actually observed later. The stoichiometric ratio of the reduced products $\left(\mathrm{H}_{2}\right.$ and $\left.\mathrm{CO}\right)$ and oxidized products $\left(\mathrm{O}_{2}\right)$ did not confirmed in the present study, which might be due to the small amount of production and large experimental error to determine the amount of $\mathrm{O}_{2}$. However, as discussed in the ESI, there are further some possible reasons for this phenomenon, such as photoadsorption of $\mathrm{O}_{2}$ on the photocatalyst surface [40-44], the competitive oxidation of water to hydrogen peroxide [45], and the competitive oxidation of $\mathrm{Cl}^{-}$anion, which is a possible residual from the flux, to form 
chlorine $\left(\mathrm{Cl}_{2}\right)$ and then hypochlorite species $\left(\mathrm{ClO}^{-}\right)$[46]. To clarify this phenomenon, further study is necessary.

Some kinds of blank tests confirmed that the photocatalyst, light, water, $\mathrm{CO}_{2}$ gas were absolutely necessary to yield $\mathrm{CO}$. Although $\mathrm{CO}$ was produced from $\mathrm{CO}_{2}$ or $\mathrm{NaHCO}_{3}$ by photochemical reaction with the irradiated light even in the absence of the photocatalyst or water, the amount of CO was very small. In addition, it was also confirmed that the Ag cocatalyst well accelerated the $\mathrm{CO}_{2}$ reduction, which is believed to be the active sites for $\mathrm{CO}$ production [17-26]. Even if the number of all Ag atoms in the reactor was used as the number of the active sites, the estimated turnover numbers for $\mathrm{CO}$ production for $24 \mathrm{~h}\left(\mathrm{TON}_{24 \mathrm{~h}}\right)$ were larger than 5 over the $\mathrm{Ag} / \mathrm{NTO}\left(\mathrm{NaCl}, 50,-10 \mathrm{Kh}^{-1}\right)$ sample, which exhibited the highest $\mathrm{CO}$ production in the present study. In addition, the reaction took place continuously even after $25 \mathrm{~h}$ at the constant rate. These results show that the reduction of $\mathrm{CO}_{2}$ in the present system proceeds photocatalytically. However, the reaction rate was still too low to estimate the quantum yield exactly in this condition.

The production rates of $\mathrm{CO}$ and $\mathrm{H}_{2}$ after the reaction for 6 and $24 \mathrm{~h}$ over the $\mathrm{Ag} / \mathrm{Na}_{2} \mathrm{Ti}_{6} \mathrm{O}_{13}$ photocatalysts are listed in Table 2. As mentioned above, although the production of $\mathrm{O}_{2}$ was really observed, the production rates are not listed in Table 2 since the evaluation would be often imprecise.

The results in Table 2, entries 1-4 show the effect of the fluxes. Among the four samples, the $\mathrm{Ag} / \mathrm{NTO}(\mathrm{NaCl}, 50)$ sample exhibited the highest $\mathrm{CO}$ production rate (Table 2, entry 2). The $\mathrm{Ag} / \mathrm{NTO}(\mathrm{KCl}, 50)$ sample (actually, $\left.\mathrm{Ag} / \mathrm{Na}_{1.46} \mathrm{~K}_{0.54} \mathrm{Ti}_{6} \mathrm{O}_{13}\right)$ with similar crystal structure to the $\mathrm{Ag} / \mathrm{NTO}(\mathrm{NaCl}, 50)$ sample exhibited higher $\mathrm{CO}$ production rate than the others, i.e., the $\mathrm{Ag} / \mathrm{NTO}(\mathrm{LiCl}, 50)$ sample and the $\mathrm{Ag} / \mathrm{NTO}\left(\mathrm{CaCl}_{2}, 50\right)$ sample (Table 2, entries 1, 3, and 4). This result suggests that the sample of the $\mathrm{Na}_{2} \mathrm{Ti}_{6} \mathrm{O}_{13}$ crystal structure exhibited higher photocatalytic activity.

The results in Table 2, entries 2 and 5-8 show the effect of the flux method and the solute concentrations in the molten mixture. The Ag/NTO(SS) sample prepared by the solid state reaction method (Table 2, entry 8) gave a lower $\mathrm{CO}$ production rate than the $\mathrm{Ag} / \mathrm{NTO}(\mathrm{NaCl}, x)$ samples prepared by the flux method (Table 2 , entry 2 and 5-7), indicating that the present flux method would be more suitable for the preparation of the $\mathrm{Na}_{2} \mathrm{Ti}_{6} \mathrm{O}_{13}$ photocatalyst for the $\mathrm{CO}_{2}$ reduction by water. Further, the photocatalytic activity of the $\mathrm{Ag} / \mathrm{NTO}(\mathrm{NaCl}, \mathrm{x})$ samples also varied with the solute concentration. Fig. $8 \mathrm{~A}$ shows the variation of the $\mathrm{CO}$ production rate on these samples with the solute concentration, $x$, where the result on the $\mathrm{Ag} / \mathrm{NTO}(\mathrm{SS})$ sample (Table 2 entry 8) was also plotted at $x=100$. The CO production rate increased with an increase of 
the solute concentration to the maximum at $50 \mathrm{~mol} \%$ and then decreased, which were so-called volcanoshaped plots. On the other hand, Fig. 8B shows the variation of the average length and width of the rod-like crystals (Table 1, entries 1-5) with the solute concentration. Although the length of the rod-like crystals simply decreased with increasing the solute concentration, the width increased then decreased, where the maximum was found at $50 \mathrm{~mol} \%$. It is interesting that both $\mathrm{CO}$ production rate and the width of the rod-like crystals similarly varied with the solute concentration to show the volcano-shaped plots, suggesting a relationship between them. Such a volcano-shaped plot was not observed for the BET specific surface area listed in Table 1.

The holding temperature of the molten mixture also affected the photocatalytic activity (Table 2, entries 5, 9 and 10). The $\mathrm{Ag} / \mathrm{NTO}(\mathrm{NaCl}, 5,973 \mathrm{~K})$ sample, which did not consist of pure $\mathrm{Na}_{2} \mathrm{Ti}_{6} \mathrm{O}_{13}$ phase, exhibited very low activity for the $\mathrm{CO}$ production (Table 2, entry 9). The $\mathrm{Ag} / \mathrm{NTO}(\mathrm{NaCl}, 5,1073 \mathrm{~K})$ sample exhibited higher activity for the $\mathrm{CO}_{2}$ reduction at $24 \mathrm{~h}$ than the $\mathrm{Ag} / \mathrm{NTO}(\mathrm{NaCl}, 5)$ sample prepared by the high holding temperature at $1273 \mathrm{~K}$ (Table 2, entries 5 and 10). The higher surface area of this sample treated lower temperature at $1073 \mathrm{~K}$ might contribute the high photocatalytic activity.

The Ag/NTO $\left(\mathrm{NaCl}, 50,-10 \mathrm{Kh}^{-1}\right)$ sample and the $\mathrm{Ag} / \mathrm{NTO}\left(\mathrm{NaCl}, 50,-5 \mathrm{Kh}^{-1}\right)$ sample, prepared with the low cooling rate (Table 2 entries 11 and 12), exhibited much higher CO production rate than the $\mathrm{Ag} / \mathrm{NTO}(\mathrm{NaCl}, 50)$ sample prepared with the high cooling rate, $-100 \mathrm{~K} \mathrm{~h}^{-1}$ (Table 2 entry 2), i.e., the sample prepared with the slower cooling rate, consisting of thicker rod-like $\mathrm{Na}_{2} \mathrm{Ti}_{6} \mathrm{O}_{13}$ crystals, exhibited higher $\mathrm{CO}$ production rate. The $\mathrm{Ag} / \mathrm{NTO}\left(\mathrm{NaCl}, 50,-10 \mathrm{Kh}^{-1}\right)$ sample exhibited 8 times higher $\mathrm{CO}$ production rate than the Ag/NTO(SS) sample after the reaction for $24 \mathrm{~h}$.

The $\mathrm{Ag} / \mathrm{NTO}(\mathrm{NaCl}, 50$, anatase $)$ sample prepared from anatase $\mathrm{TiO}_{2}$ powder with high specific surface area, consisting of the fine rod-like crystals, showed a lower $\mathrm{CO}$ production rate than the corresponding sample prepared from rutile, i.e., the $\mathrm{Ag} / \mathrm{NTO}(\mathrm{NaCl}, 50)$ sample (Table 2, entry 2 and 13 ). But it showed a higher rate than the $\mathrm{Ag} / \mathrm{NTO}(\mathrm{SS})$ sample (Table 2, entry 5).

As a conclusion of this section, the efficient preparation conditions are summarized: The high activity for CO production was obtained by the thick rod-like $\mathrm{Na}_{2} \mathrm{Ti}_{6} \mathrm{O}_{13}$ crystals prepared in the flux method from rutile $\mathrm{TiO}_{2}$ by using moderate amount of $\mathrm{NaCl}$ flux through high holding temperature at $1073 \mathrm{~K}$ or $1273 \mathrm{~K}$ and the moderately slow cooling rate of $-10 \mathrm{~K} \mathrm{~h}^{-1}$. This is the relation between the preparation conditions and the 
photocatalytic activity. However, fundamentally it is more important to know the relationship between the structure and the photocatalytic activity, which will be discussed further in the next section.

\subsection{Relation between the structure and the photocatalytic activity}

Fig. 9 shows the relationship between the average width of the rod-like crystals or the particle size in the various $\mathrm{Na}_{2} \mathrm{Ti}_{6} \mathrm{O}_{13}$ samples and the photocatalytic activity for $\mathrm{CO}_{2}$ reduction over the corresponding $\mathrm{Ag}$ loaded samples (Table 2, entries 2, 5-8, and 11-13). These $\mathrm{Na}_{2} \mathrm{Ti}_{6} \mathrm{O}_{13}$ samples were prepared by the flux method by using $\mathrm{NaCl}$ flux with various solute concentrations of $5-70 \%$ in the molten mixture, with various cooling rates $\left(-100,-10\right.$ or $\left.-5 \mathrm{~K} \mathrm{~h}^{-1}\right)$ and from rutile or anatase as the starting material. The sample prepared by the solid-state reaction method is also included. All these samples were prepared through heating at 1273 $\mathrm{K}$, and the same amount of $\mathrm{Ag}(0.1 \mathrm{wt} \%)$ was loaded on them.

As clearly shown, a good relationship was obtained between them, i.e., the thick rod-like crystal exhibited higher photocatalytic activity for the $\mathrm{CO}_{2}$ reduction to produce $\mathrm{CO}$ molecule, typically larger than $0.7 \mu \mathrm{m}$ in width. Similar correlation was also found in our previous study for the photocatalytic $\mathrm{CO}_{2}$ reduction with $\mathrm{Ag} / \mathrm{CaTiO}_{3}$ photocatalysts similarly prepared by the flux method [25]. Especially the $\mathrm{Na}_{2} \mathrm{Ti}_{6} \mathrm{O}_{13}$ samples prepared with the slow cooling rate exhibited higher activity, which would originate from the large width of the $\mathrm{Na}_{2} \mathrm{Ti}_{6} \mathrm{O}_{13}$ crystals such as $1.3 \mu \mathrm{m}$. The aspect ratio of 3.2-3.9 of the thick rod-like structure of these samples (Table 1, entries 8 and 9) might provide a good balance for both reductive and oxidative reactions. It is noted that the clear relationship was found with the $\mathrm{CO}$ formation rate but not with the $\mathrm{H}_{2}$ production rate, the thick structure might be responsible for the state of the Ag nanoparticles as the cocatalyst for the CO production.

\subsection{Variation of the Ag cocatalyst nanoparticles}

Here, the state of the Ag nanoparticles will be discussed. Fig. 10 shows SEM images of the representative $\mathrm{Ag} / \mathrm{Na}_{2} \mathrm{Ti}_{6} \mathrm{O}_{13}$ photocatalysts before and after the photocatalytic reaction test. Since these SEM images were recorded in the reflection mode, the bright dots indicate the Ag nanoparticles. Before the reaction test, only a few and very small white dots could be observed on the $\mathrm{Ag} / \mathrm{NTO}(\mathrm{NaCl}, 5)$ sample and the $\mathrm{Ag} / \mathrm{NTO}(\mathrm{NaCl}, 50)$ sample, suggesting that the most of the $\mathrm{Ag}$ nanoparticles would be small and well dispersed on the crystals (Fig. 10, a and b). The images recorded after using in the reaction tests showed 
some larger Ag nanoparticles (Fig. 10, d and e). It is thus proposed that the Ag nanoparticles could aggregate during the photocatalytic reaction. The aggregation was observed also on the $\mathrm{Ag} / \mathrm{NTO}(\mathrm{SS})$ sample (Fi. 10, $\mathrm{c}$ and $\mathrm{f}$ ). This would be the reasons why the photocatalytic production rates varied with time in the initial period.

As for the variation of the state of the Ag nanoparticles, two possibilities are considered as follows: (i) The Ag nanoparticles might migrate on the surface of the $\mathrm{Na}_{2} \mathrm{Ti}_{6} \mathrm{O}_{13}$ crystals under photoirradiation and aggregate to become larger particles. (ii) On the oxidative facets, where the photocatalytic oxidation by positive holes preferably occur, $\mathrm{Ag}$ atoms in the Ag nanoparticles could be oxidized and dissolved into aqueous solution as $\mathrm{Ag}^{+}$cations, and then they would be deposited and reduced on other $\mathrm{Ag}$ nanoparticles located on the reductive facets, where the photocatalytic reduction preferably occur by the photoexcited electron, as illustrated in Fig. 11.

In the previous study of the $\mathrm{Ag} / \mathrm{CaTiO}$ photocatalysts [25], the $\mathrm{CaTiO}_{3}$ crystals were similarly prepared by a flux method and facets were observed on the crystals. After the photocatalytic reaction test, the Ag nanoparticles were found only on some selected facets of the $\mathrm{CaTiO}_{3}$ crystals, where the reductive reaction with excited electrons should take place preferentially. In other words, the place stabilizing the Ag nanoparticles would be the reductive sites in the photocatalytic reaction. The Ag cocatalyst nanoparticles stabilized on the reductive sites would be very effective for the photocatalytic $\mathrm{CO}_{2}$ reduction since the $\mathrm{Ag}$ nanoparticles were considered as the receiver of the excited electrons and the cocatalyst to promote the $\mathrm{CO}_{2}$ reduction to $\mathrm{CO}$.

In the present study, it was notable that the $\mathrm{Ag}$ nanoparticles lined along the rod-like crystals in the direction of the long axis on the $\mathrm{Ag} / \mathrm{NTO}(\mathrm{NaCl}, 50)$ sample after the photocatalytic reaction test (Fig. 10e). It seems that the particles are supported by two neighboring facets of the aggregated rod-like crystals, which correspond to the faces vertical to (010) plane such as (001) plane [27]. Since the Ag nanoparticles were stabilized on the long facets, these neighboring facets of the rod-like crystals would be the reductive sites. It is proposed that the neighboring two reductive facets would stabilize the Ag nanoparticles on them from the two directions and more efficiently supply the photoexcited electrons for the two electron step for CO formation (eq. 3), which should contribute to the high activity for the $\mathrm{CO}$ production in the photocatalytic $\mathrm{CO}_{2}$ reduction (Fig. 12). The wide reductive surface would be suitable for holding the large numbers of the 
Ag cocatalyst, which would be one of the reasons why the photocatalytic $\mathrm{CO}_{2}$ reduction was enhanced with the thick rod-like crystals.

The structural variation of the $\mathrm{Ag}$ nanoparticles on the $\mathrm{Na}_{2} \mathrm{Ti}_{6} \mathrm{O}_{13}$ samples under the photocatalytic reaction condition was observed in the DR UV-vis spectra of the Ag/NTO(NaCl,50) sample (Fig. S4). The SPR band around $500 \mathrm{~nm}$ originated from metallic Ag nanoparticles (Fig. S4a) changed to a broad and weak one (Fig. S4b), indicating that the nanoparticles would change in the size or the oxidation state, supporting the dynamic variation of the Ag nanoparticles as mentioned above. From Ag K-edge XANES spectra of the $\mathrm{Ag} / \mathrm{NTO}(\mathrm{NaCl}, 50)$ sample before and after the photocatalytic reaction test (Fig. S5, b and c), it was suggested that the $\mathrm{Ag} / \mathrm{NTO}(\mathrm{NaCl}, 50)$ samples before and after the reaction would consist of metallic and oxidized $\mathrm{Ag}$ species, suggesting that the Ag cocatalyst nanoparticles would be easily oxidized and reduced during the photocatalytic reaction. This supports the proposed mechanism shown in Fig. 11.

When an aqueous solution of $\mathrm{Na}_{2} \mathrm{CO}_{3}(\mathrm{pH}=11)$ was used for the photocatalytic reaction test with the $\mathrm{Ag} / \mathrm{NTO}(\mathrm{NaCl}, 30)$ sample (Table 2 , entry 14$)$, the $\mathrm{CO}$ production rate and the $\mathrm{CO}$ selectivity were higher than that in the solution of $\mathrm{NaHCO}_{3}(\mathrm{pH}=8.3-9.2)$ (Table 2, entry 6). Although the different reaction condition might change the concentration of dissolved $\mathrm{CO}_{2}$ species in the solution and thus it might increase the reaction rate, the variation of the Ag nanoparticles during the photocatalytic reaction is discussed in the present study. The zero point of charge for the $\mathrm{Na}_{2} \mathrm{Ti}_{6} \mathrm{O}_{13}$ crystals measured by the titration method using the $\mathrm{NTO}(\mathrm{NaCl}, 50)$ sample was $\mathrm{pH}_{\mathrm{ZPC}}=9.3$, meaning that the surface of the $\mathrm{Na}_{2} \mathrm{Ti}_{6} \mathrm{O}_{13}$ crystal would be positively charged or close to neutral in the $\mathrm{NaHCO}_{3}$ solution and negatively charged in the $\mathrm{Na}_{2} \mathrm{CO}_{3}$ solution. The DR UV-visible spectra after the reaction in this condition (Fig. S4c) showed that the Ag nanoparticles on the negatively charged surface still exhibited the surface plasmon resonance and shifted to shorter wavelength, meaning that the Ag nanoparticles would become more dispersed during the reaction. It is proposed that the dissolved $\mathrm{Ag}^{+}$cation would be preferentially deposited on the negative $\mathrm{Na}_{2} \mathrm{Ti}_{6} \mathrm{O}_{13}$ crystal surface rather than the $\mathrm{Ag}$ nanoparticles, which would be tend to enhance the dispersion of the $\mathrm{Ag}$ nanoparticles on the reductive surface and contribute to the enhancement of the $\mathrm{CO}$ production rate. In this condition the highest $\mathrm{CO}$ selectivity such as $60 \%$ was achieved (Table 2, entry 14), which might be contributed by the highly dispersed Ag nanoparticles as the cocatalyst for the CO production. On the other hand, the Ag nanoparticles on the positive or neutral surface lost the SPR feature of nanoparticle during the photocatalytic reaction test (Fig. S4b) and the $\mathrm{CO}$ formation rate decreased drastically (Table 2, entry 6) 
compared to the negatively charged surface (Table 2, entry 14), which would be due to the aggregation of the Ag nanoparticles. The control of the Ag species would be one of the key factors to realize the high photocatalytic performance.

\section{Conclusions}

In the present study, several kinds of $\mathrm{Ag}$ loaded $\mathrm{Na}_{2} \mathrm{Ti}_{6} \mathrm{O}_{13}$ photocatalysts were prepared with the flux method and the photodeposition method, and the samples were examined for the photocatalytic $\mathrm{CO}_{2}$ reduction by water in the aqueous solution of $\mathrm{NaHCO}_{3}$, which produced $\mathrm{CO}, \mathrm{H}_{2}$ and $\mathrm{O}_{2}$. The highest $\mathrm{CO}$ production rate in the current reaction condition was $0.89 \mu \mathrm{mol} \mathrm{h}^{-1}$ at the steady state $(24 \mathrm{~h}$ later) over the $\mathrm{Ag} / \mathrm{NTO}\left(\mathrm{NaCl}, 50,-10 \mathrm{Kh}^{-1}\right)$ sample, although this value was one third lower than a $\mathrm{Ag} / \mathrm{CaTiO}_{3}$ photocatalyst of the same Ag content reported in our previous study [25]. It should be mentioned that the production rate of $\mathrm{H}_{2}$ was much higher than the previous one, implying that the optimization of the loading amount, the structure of the $\mathrm{Ag}$ cocatalyst and so on, may contribute to the further improvement of the $\mathrm{CO}$ production rate.

The highest $\mathrm{CO}$ rate achieved with the $\mathrm{Na}_{2} \mathrm{Ti}_{6} \mathrm{O}_{13}$ photocatalyst consisting of thick rod-like crystals, which was obtained by the flux method by using the $\mathrm{NaCl}$ flux with $50 \%$ of solute concentration in the molten mixture at high holding temperature $(1273 \mathrm{~K})$ and followed by the slow cooling rate such as $-10 \mathrm{~K}$ $\mathrm{h}^{-1}$. The large side facets such as (001) plane are the reductive facets, which can stabilize the Ag nanoparticles on them and supply the photoexcited electrons to the Ag cocatalyst for the CO production. The thick rod-like structure with suitable aspect ratio such as 3.2 would realize a good balance for both reductive and oxidative reactions, realizing high photocatalytic performance for $\mathrm{CO}$ production as a result.

On the other hand, the highest selectivity for the CO production in the present study was $60 \%$ when the photocatalytic reaction was carried out in the basic aqueous solution of $\mathrm{Na}_{2} \mathrm{CO}_{3}$, where the highly dispersed Ag cocatalyst nanoparticles would be formed more. It is expected that further optimization of the reaction condition would also improve the photocatalytic activity for both the $\mathrm{CO}$ production rate and the $\mathrm{CO}$ selectivity. This will be examined in the next study.

\section{Acknowledgements}


The SEM measurements were partly carried out by the support of Nano-fabrication platform at VBL, Nagoya University, under Nanotechnology platform, the Ministry of Education, Culture, Sports, Science and Technology (MEXT), Japan. The XAFS experiments were performed under the approval of the Photon Factory Program Advisory Committee (proposal no. 2014G547). The authors thank to Prof. T. Tanaka, Kyoto University, for the ICP measurement. This work was financially supported by Toyota Motor Corporation, as well as a Grant-in-Aid for Scientific Research (B), (No. 25289285), a Grant-in-Aid for Scientific Research on Innovative Areas “All Nippon Artificial Photosynthesis Project for Living Earth (AnApple)" (No. 25107515) from JSPS, and the Program for Element Strategy Initiative for Catalysts \& Batteries (ESICB), commissioned by the MEXT of Japan.

\section{Appendix A. Supplementary data}

Electronic supplementary information (ESI) is available on the web.

\section{References}

[1] T.F. Stocker, D. Qin, G.K. Plattner, M.M.B. Tignor, S.K. Allen, J. Boschung, A. Nauels, Y. Xia, V. Bex, P.M. Midgley, Climate Change 2013: The Physical Science Basis, Cambridge University Press, Cambridge, 2013.

[2] N.S. Lewis, D.G. Nocera, Proc. Natl. Acad. Sci. USA 103 (2006) 15729-15735.

[3] V. Balzani, A. Credi, M. Venturi, ChemSusChem 1 (2008) 26-58.

[4] A. Kudo, Y. Miseki, Chem. Soc. Rev. 38 (2009) 253-278.

[5] K. Maeda, K. Domen, J. Phys. Chem. Lett. 1 (2010) 2655-2661.

[6] O. Ishitani, CSJ Current Review 2 (2010) 81-87.

[7] H. Inoue, T. Shimada, Y. Kou, Y. Nabetani, D. Masui, S. Takagi, H. Tachibana, ChemSusChem 4 (2011) 173-179.

[8] H. Yoshida, Photocatalytic conversion of carbon dioxide, in: Z. Ling (Eds.), Energy Efficiency and Renewable Energy Through Nanotechnology, Green Energy and Technology, Springer-Verlag, London, 2011, chapter 15 , pp. 531-559.

[9] J.C. Hemminger, R. Carr, G.A. Somorjai, Chem. Phys. Lett. 57 (1978) 100-104. 
[10] M. Halmann, Nature 275 (1978) 115-116.

[11] T. Inoue, A. Fujishima, S. Konishi, K. Honda, Nature 277 (1979) 637-638.

[12] O. Ishitani, C. Inoue, Y. Suzuki, T. Ibusuki, J. Photo. Photo. A 72 (1993) 269-271.

[13] S. Sato, T. Arai, T. Morikawa, K. Uemura, T. M. Suzuki, H. Tanaka, T. Kajino, J. Am. Chem. Soc. 133 (2011) 15240-15243.

[14] T. Arai, S. Sato, T. Kajino, T. Morikawa, Energy Envirn. Sci. 6 (2013) 1274-1282.

[15] S. N. Habisreutinger, L. Schmidt-Mende, J. K. Stolarczyk, Angew. Chem. Int. Ed. 52 (2013) 7372-7408.

[16] K. Sayama, H. Arakawa, J. Phys. Chem. 97 (1993) 531-533.

[17] K. Iizuka, T. Wato, Y. Miseki, K. Saito, A. Kudo, J. Am. Chem. Soc. 133 (2011) 20863-20868.

[18] N. Yamamoto, T. Yoshida, S. Yagi, Z. Like, T. Mizutani, S. Ogawa, H. Nameki, H. Yoshida, J. Surf. Sci. Nanotechnol. 12 (2014) 263-268.

[19] M. Yamamoto, T. Yoshida, N. Yamamoto, H. Yoshida, S. Yagi, J. Surf. Sci. Nanotechnol. 12 (2014) 299303.

[20] M. Yamamoto, T. Yoshida, N. Yamamoto, T. Nomoto, Y. Yamamoto, S. Yagi, H. Yoshida, J. Mater. Chem. A 3 (2015) 16810-16816.

[21] M. Yamamoto, T. Yoshida, N. Yamamoto, T. Nomoto, A. Yamamoto, H. Yoshida, and S. Yagi, J. Phys.: Conf. Ser. 712 (2016) 012074.

[22] K. Teramura, Z. Wang, S. Hosokawa, Y. Sakata, T. Tanaka, Chem. Eur. J. 20 (2014) 9906-9909.

[23] T. Takayama, K. Tanabe, K. Saito, A. Iwase, A. Kudo, Phys. Chem. Chem. Phys. 16 (2014) 24417-24422.

[24] Z. Wang, K. Teramura, S. Hosokawa, T. Tanaka, Appl. Catal. B 163 (2015) 241-247.

[25] H. Yoshida, L. Zhang, M. Sato, T. Morikawa, T. Kajino, T. Sekito, S. Matsumoto, H. Hirata, Catal. Today 251 (2015) 132-139.

[26] A. Anzai, N. Fukuo, A. Yamamoto, H. Yoshida, Catal. Commun. 100 (2017) 134-138.

[27] K. Teshima, K. Yubuta, S. Sugiura, T. Suzuki, T. Shishido, S. Oishi, Bull. Chem. Soc. Jpn. 79 (2006) $1725-1728$.

[28] C.Y. Xu, J. Wu, P. Zhang, S.P. Hu, J.X. Cui, Z.Q. Wang, Y.D. Huang, L. Zhen, Crys-tEngComm 15 (2013) $3448-3454$. 
[29] S. Suzuki, K. Teshima, M. Kiyohara, H. Kamikawa, K. Yubuta, T. Shishido, S. Oishi, CrystEngComm 14 (2012) 4176-4180.

[30] H. Yoshida, M. Takeuchi, M. Sato, L. Zhang, T. Teshima, M.G. Chaskar, Catal. Today 232 (2014) 158164.

[31] H. Kato, M. Kobayashi, M. Hara, M. Kakihana, Catal. Sci. Technol. 3 (2013) 1733-1738.

[32] D. Arney, B. Porter, B. Greve, P.A. Maggard, J. Photochem. Photobiol. 199 (2008) 230-235.

[33] Q. Wang, T. Hisatomi, Y. Moriya, K. Maeda, K. Domen, Catal. Sci. Technol. 3 (2013) 2098-2103.

[34] D. Arney, T. Watkins, P.A. Maggardw, J. Am. Ceram. Soc. 94 (2011) 1483-1489.

[35] Y. Miseki, K. Saito, A. Kudo, Chem. Lett. 38 (2009) 180-181.

[36] Y. Hosogi, H. Kato, A. Kudo, J. Mater. Chem. 18 (2008) 647-653.

[37] K. Shimura, H. Kawai, T. Yoshida, H. Yoshida, ACS Catal. 2 (2012) 2126-2134.

[38] K. Shimura, H. Yoshida, Energy Environ. Sci. 4 (2011) 2467-2481.

[39] K. Kataoka, J. Awaka, N. Kijima, H. Hayakawa, K. Ohshima, J. Akimoto, Chem. Mater. 23 (2011) 23442352.

[40] G. Muneura, V. Rives-Arnau, A. Saucedo, J. Chem. Soc. Faraday Trans. 175 (1979) 736-747.

[41] A. Gonzalez-Elipe, G. Muneura, J. Soria, J. Chem. Soc. Faraday Trans. 175 (1979) 748-761.

[42] K. Yamaguchi, S. Sato, J. Phys. Chem. 89 (1985) 5510-5513.

[43] J. Kiwi, M. Grätzel, J. Phys. Chem. 88 (1984) 1302-1307.

[44] J. Kiwi, C. Morrison, J. Phys. Chem. 88 (1984) 6146-6152.

[45] H. Muraki, T. Saji, M. Fujihira, S. Aoyagui, J. Electroanal. Chem. 169 (1984) 319-323.

[46] S. Iguchi, K. Teramura, S. Hosokawa, T. Tanaka, Catal. Today 251 (2015) 140-144. 
Tables.

Table 1 The average sizes of the rod-like crystals in the NTO samples.

\begin{tabular}{|c|c|c|c|c|c|}
\hline \multirow[t]{2}{*}{ Entry } & \multirow[t]{2}{*}{ Sample } & \multicolumn{2}{|c|}{$\begin{array}{l}\text { average size of } \\
\text { crystals }^{a} / \mu \mathrm{m}\end{array}$} & \multirow[b]{2}{*}{ aspect ratio } & \multirow{2}{*}{$\begin{array}{l}\mathrm{S}_{\mathrm{BET}}{ }^{b} \\
/ \mathrm{m}^{2} \mathrm{~g}^{-1}\end{array}$} \\
\hline & & length & width & & \\
\hline \multicolumn{6}{|c|}{ Various solute concentration, $x$} \\
\hline $1^{\mathrm{c}}$ & $\mathrm{NTO}(\mathrm{NaCl}, 5)$ & 6.4 & 0.74 & 8.7 & 2.0 \\
\hline $2^{c}$ & $\mathrm{NTO}(\mathrm{NaCl}, 30)$ & 4.3 & 0.81 & 5.3 & \\
\hline $3^{c}$ & $\mathrm{NTO}(\mathrm{NaCl}, 50)$ & 4.1 & 1.1 & 3.9 & 1.8 \\
\hline $4^{\mathrm{c}}$ & $\mathrm{NTO}(\mathrm{NaCl}, 70)$ & 2.4 & 0.91 & 2.6 & \\
\hline 5 & NTO(SS) & 0.88 & 0.68 & 1.3 & 1.6 \\
\hline \multicolumn{6}{|c|}{ Various hold temperatures } \\
\hline $6^{d}$ & $\mathrm{NTO}(\mathrm{NaCl}, 5,973 \mathrm{~K})$ & 1.2 & 0.049 & 25 & \\
\hline 7 & $\mathrm{NTO}(\mathrm{NaCl}, 5,1073 \mathrm{~K})$ & 6.2 & 0.33 & 18 & 3.6 \\
\hline \multicolumn{6}{|c|}{ Various cooling rate } \\
\hline 8 & $\mathrm{NTO}\left(\mathrm{NaCl}, 50,-10 \mathrm{Kh}^{-1}\right)$ & 4.1 & 1.3 & 3.2 & \\
\hline 9 & $\mathrm{NTO}\left(\mathrm{NaCl}, 50,-5 \mathrm{Kh}^{-1}\right)$ & 4.7 & 1.3 & 3.8 & \\
\hline \multicolumn{6}{|c|}{ Using anatase $\mathrm{TiO}_{2}$ as a start material } \\
\hline 10 & NTO(NaCl,50, anatase) & 1.7 & 0.24 & 7.2 & \\
\hline \multicolumn{6}{|c|}{$\begin{array}{l}{ }^{a} \text { The variation coefficient ranged between } 28-62 \% .{ }^{b} \text { BET specific surface area. } \\
{ }^{c} \text { Samples were heated at } 1273 \mathrm{~K} \text { for } 10 \mathrm{~h} \text {, and cooled at a rate of }-100 \mathrm{~K} \mathrm{~h}^{-1} .^{d} \\
\text { the data for the rod-like crystals in the mixture. }\end{array}$} \\
\hline
\end{tabular}


Table 2 Results of the reaction tests for the photocatalytic reduction of $\mathrm{CO}_{2}$ with $\mathrm{H}_{2} \mathrm{O}$ with the $\mathrm{Ag} / \mathrm{NTO}$ samples.

\begin{tabular}{|c|c|c|c|c|c|c|}
\hline \multirow[t]{2}{*}{ Entry } & \multirow[t]{2}{*}{ Sample $^{a}$} & \multicolumn{2}{|c|}{$\begin{array}{l}\text { Production rate }(5 \mathrm{~h} \\
\text { later }) / \mu \mathrm{mol} \mathrm{h}{ }^{-1}\end{array}$} & \multicolumn{2}{|c|}{$\begin{array}{l}\text { Production rate }(24 \mathrm{~h} \\
\text { later }) / \mu \mathrm{mol} \mathrm{h} \mathrm{h}^{-1}\end{array}$} & \multirow[b]{2}{*}{$S_{C O}$} \\
\hline & & $\mathrm{CO}$ & $\mathrm{H}_{2}$ & $\mathrm{CO}$ & $\mathrm{H}_{2}$ & \\
\hline \multicolumn{7}{|c|}{ Various fluxes } \\
\hline 1 & $\mathrm{Ag} / \mathrm{NTO}(\mathrm{LiCl}, 50)$ & 0.054 & 0.708 & $-^{c}$ & $--^{c}$ & - \\
\hline 2 & $\mathrm{Ag} / \mathrm{NTO}(\mathrm{NaCl}, 50)$ & 0.155 & 0.081 & 0.042 & 0.115 & 27 \\
\hline 3 & $\mathrm{Ag} / \mathrm{NTO}(\mathrm{KCl}, 50)$ & 0.109 & 0.298 & 0.031 & 0.089 & 26 \\
\hline 4 & $\mathrm{Ag} / \mathrm{NTO}\left(\mathrm{CaCl}_{2}, 50\right)$ & 0.085 & 0.380 & 0.011 & 0.085 & 11 \\
\hline
\end{tabular}

Various solute concentration, $x$

$\begin{array}{lllllll}5 & \mathrm{Ag} / \mathrm{NTO}(\mathrm{NaCl}, 5) & 0.088 & 0.184 & 0.019 & 0.246 & 7.1 \\ 6 & \mathrm{Ag} / \mathrm{NTO}(\mathrm{NaCl}, 30) & 0.126 & 0.155 & 0.030 & 0.079 & 28 \\ 7 & \mathrm{Ag} / \mathrm{NTO}(\mathrm{NaCl}, 70) & 0.079 & 0.097 & 0.030 & 0.103 & 22 \\ 8 & \mathrm{Ag} / \mathrm{NTO}(\mathrm{SS}) & 0.022 & 0.042 & 0.011 & 0.026 & 30\end{array}$

Various hold temperatures

$9 \quad \mathrm{Ag} / \mathrm{NTO}(\mathrm{NaCl}, 5,973 \mathrm{~K}) \quad 0.017 \quad 0.168$

$\begin{array}{lllllll}10 & \mathrm{Ag} / \mathrm{NTO}(\mathrm{NaCl}, 5,1073 \mathrm{~K}) & 0.085 & 0.347 & 0.034 & 0.630 & 5.7\end{array}$

Various cooling rate

$\begin{array}{lllllll}11 & \mathrm{Ag} / \mathrm{NTO}\left(\mathrm{NaCl}, 50,-10 \mathrm{Kh}^{-1}\right) & 0.349 & 1.76 & 0.089 & 0.941 & 8.6 \\ 12 & \mathrm{Ag} / \mathrm{NTO}\left(\mathrm{NaCl}, 50,-5 \mathrm{Kh}^{-1}\right) & 0.279 & 2.30 & 0.070 & 3.14 & 2.2\end{array}$

Others

$\begin{array}{lllllll}13 & \mathrm{Ag} / \mathrm{NTO}(\mathrm{NaCl}, 50, \text { anatase }) & 0.086 & 0.636 & 0.017 & 0.214 & 7.4 \\ 14^{d} & \mathrm{Ag} / \mathrm{NTO}(\mathrm{NaCl}, 30) & 0.140 & 0.539 & 0.059 & 0.040 & 60\end{array}$

${ }^{a}$ Loading amount of $\mathrm{Ag}$ cocatalyst was $0.1 \mathrm{wt} \%$ and the used photocatalyst was $0.2 \mathrm{~g} .{ }^{b}$ Selectivity to CO after the reaction at $24 \mathrm{~h}$ later, see text. ${ }^{c}$ Not measured due to very low production rate. ${ }^{d}$ The photocatalytic reaction was carried out in an aqueous solution of $\mathrm{Na}_{2} \mathrm{CO}_{3}(\mathrm{pH}=11)$ instead of the solution of $\mathrm{NaHCO}_{3}$ $(\mathrm{pH}=8.3)$. 
Figures.

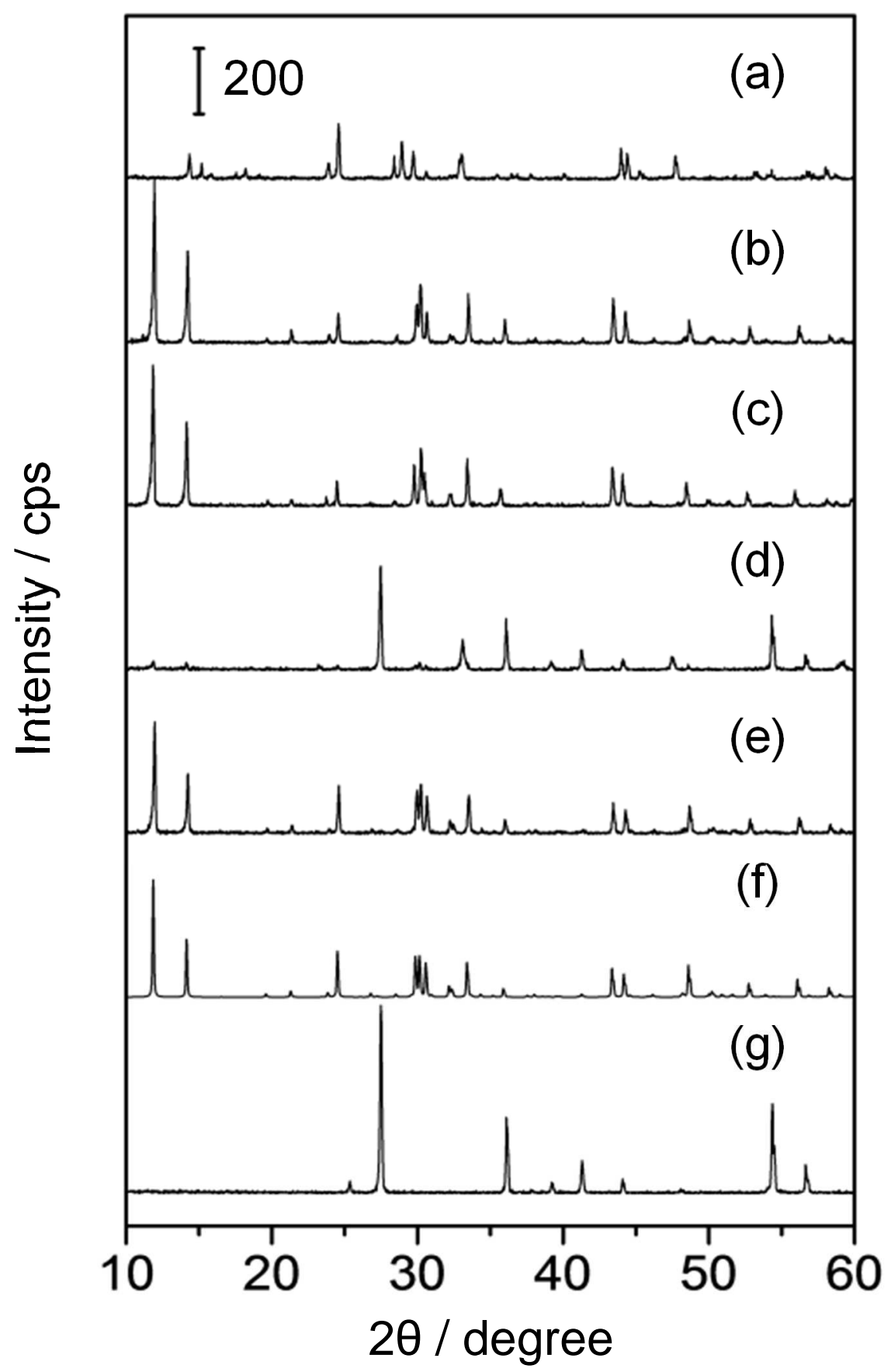

Fig. 1 XRD patterns of the prepared $\mathrm{Na}_{2} \mathrm{Ti}_{6} \mathrm{O}_{13}$ samples; the $\mathrm{NTO}(\mathrm{LiCl}, 50)$ sample $(a)$, the $\mathrm{NTO}(\mathrm{NaCl}, 50)$ sample (b), the $\mathrm{NTO}(\mathrm{KCl}, 50)$ sample (c), the $\mathrm{NTO}\left(\mathrm{CaCl}_{2}, 50\right)$ sample (d), the $\mathrm{NTO}(\mathrm{SS})$ sample (e), a calculated one from a database (ICSD\#182965) (f), and the rutile $\mathrm{TiO}_{2}$ powder as the starting material (g). The NTO samples were prepared in the standard condition (hold temperature was $1273 \mathrm{~K}$, the cooling rate was $-100 \mathrm{~K} \mathrm{~h}^{-1}$ ). 

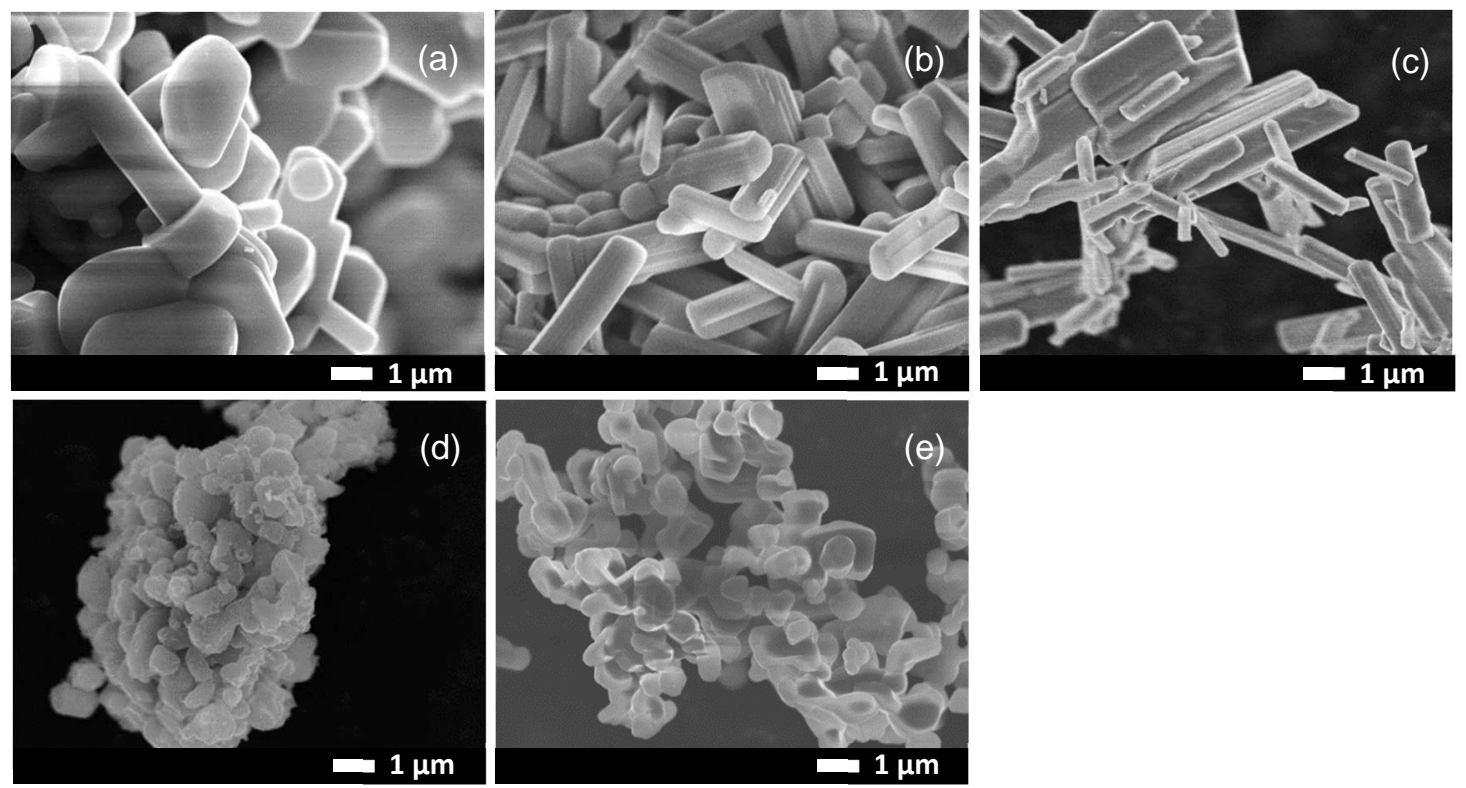

Fig. 2 SEM images of the prepared NTO samples; the $\mathrm{NTO}(\mathrm{LiCl}, 50)$ sample (a), the $\mathrm{NTO}(\mathrm{NaCl}, 50)$ sample (b), the $\mathrm{NTO}(\mathrm{KCl}, 50)$ sample (c), the $\mathrm{NTO}\left(\mathrm{CaCl}_{2}, 50\right)$ sample (d), and the $\mathrm{NTO}(\mathrm{SS})$ sample (e). The samples were prepared in the standard condition (hold temperature was $1273 \mathrm{~K}$, the cooling rate was $-100 \mathrm{~K} \mathrm{~h}^{-1}$ ).
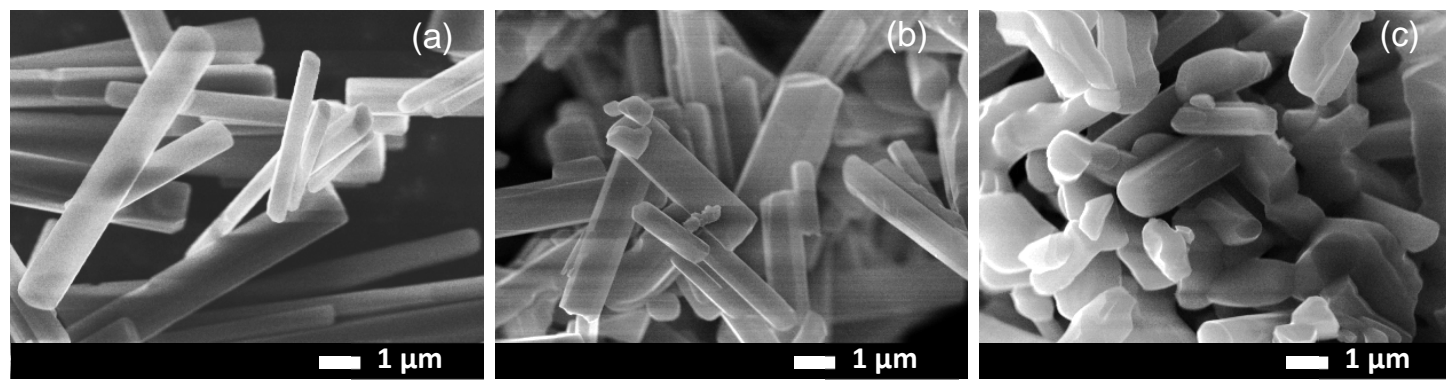

Fig. $3 \mathrm{SEM}$ images of the prepared $\mathrm{Na}_{2} \mathrm{Ti}_{6} \mathrm{O}_{13}$ samples by using $\mathrm{NaCl}$ flux with various concentrations of the solute in the molten mixture; the $\mathrm{NTO}(\mathrm{NaCl}, 5)$ sample (a), the $\mathrm{NTO}(\mathrm{NaCl}, 30)$ sample (b), and the $\mathrm{NTO}(\mathrm{NaCl}, 70)$ sample (c). The samples were prepared in the standard condition (hold temperature was 1273 $\mathrm{K}$, the cooling rate was $\left.-100 \mathrm{~K} \mathrm{~h}^{-1}\right)$. See Fig. $2 \mathrm{~b}$ for the $\mathrm{NTO}(\mathrm{NaCl}, 50)$ sample. 


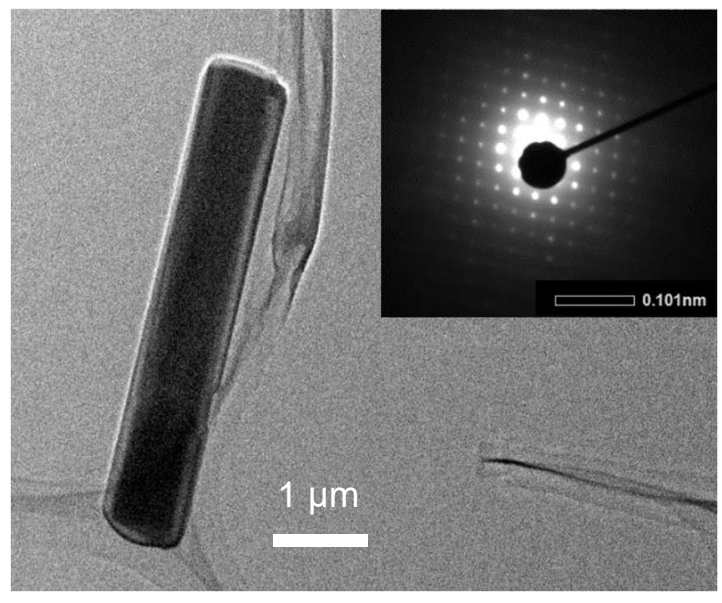

Fig. 4 TEM image and electron diffraction pattern (inset) of the $\mathrm{NTO}(\mathrm{NaCl}, 50)$ sample prepared by the flux method in the standard condition (hold temperature was $1273 \mathrm{~K}$, the cooling rate was $-100 \mathrm{~K} \mathrm{~h}^{-1}$ ).

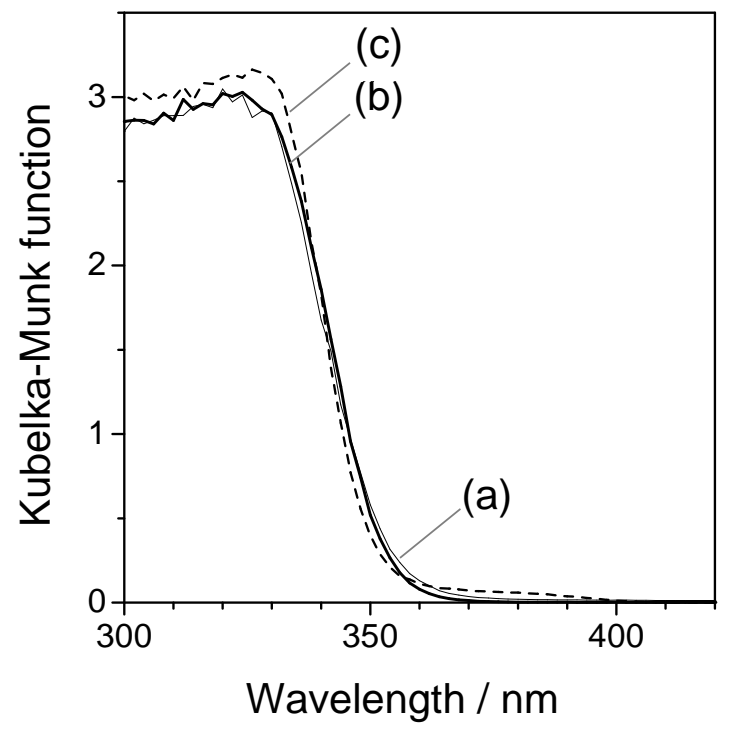

Fig. 5 DR UV-visible spectra of the prepared $\mathrm{Na}_{2} \mathrm{Ti}_{6} \mathrm{O}_{13}$ samples; the $\mathrm{NTO}(\mathrm{NaCl}, 5)$ sample (a) and the $\mathrm{NTO}(\mathrm{NaCl}, 50)$ sample (b), and the $\mathrm{NTO}(\mathrm{SS})$ sample (c). The samples were prepared in the standard condition (hold temperature was $1273 \mathrm{~K}$, the cooling rate was $-100 \mathrm{~K} \mathrm{~h}^{-1}$ ). 


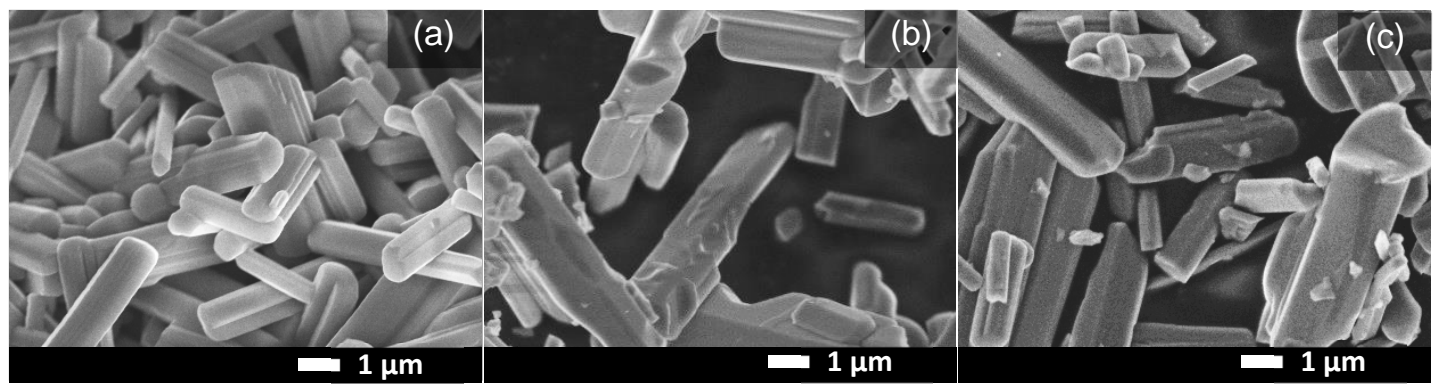

Fig. 6 SEM images of the $\mathrm{NTO}\left(\mathrm{NaCl}, 50,-100 \mathrm{Kh}^{-1}\right)$ sample (a), the $\mathrm{NTO}\left(\mathrm{NaCl}, 50,-10 \mathrm{Kh}^{-1}\right)$ sample (b), and the $\mathrm{NTO}\left(\mathrm{NaCl}, 50,-5 \mathrm{Kh}^{-1}\right)$ sample (c). Image (a) is shown again for comparison, which is the same as Fig. 2c.

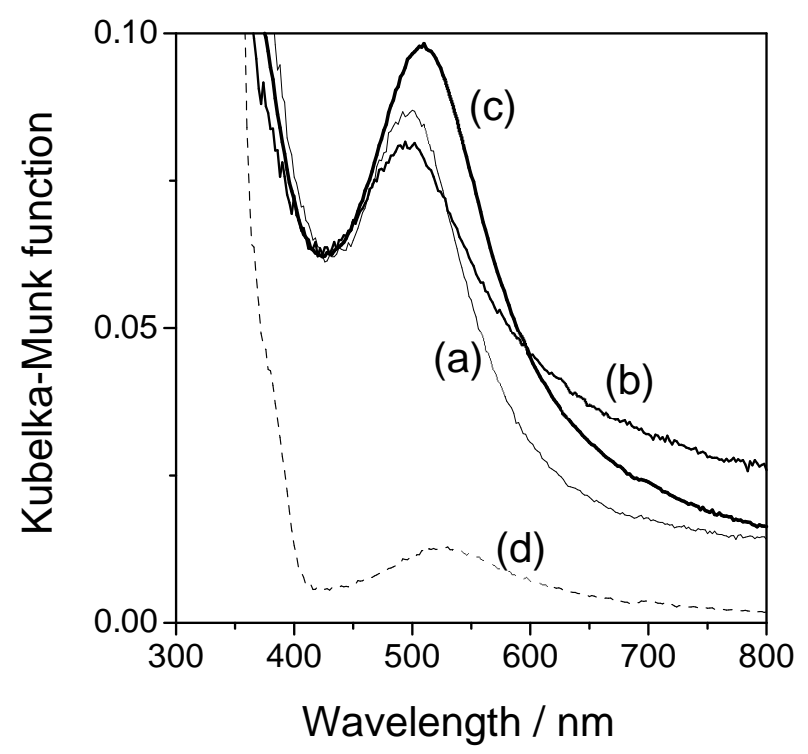

Fig. 7 DR UV-visible spectra of the $\mathrm{Ag} / \mathrm{NTO}(\mathrm{NaCl}, 5)$ sample (a), the $\mathrm{Ag} / \mathrm{NTO}(\mathrm{NaCl}, 50)$ sample (b) and the $\mathrm{Ag} / \mathrm{NTO}(\mathrm{NaCl}, 70)$ sample (c), and the $\mathrm{Ag} / \mathrm{NTO}(\mathrm{SS})$ sample (d). The samples were prepared in the standard condition (hold temperature was $1273 \mathrm{~K}$, the cooling rate was $-100 \mathrm{~K} \mathrm{~h}^{-1}$ ). 

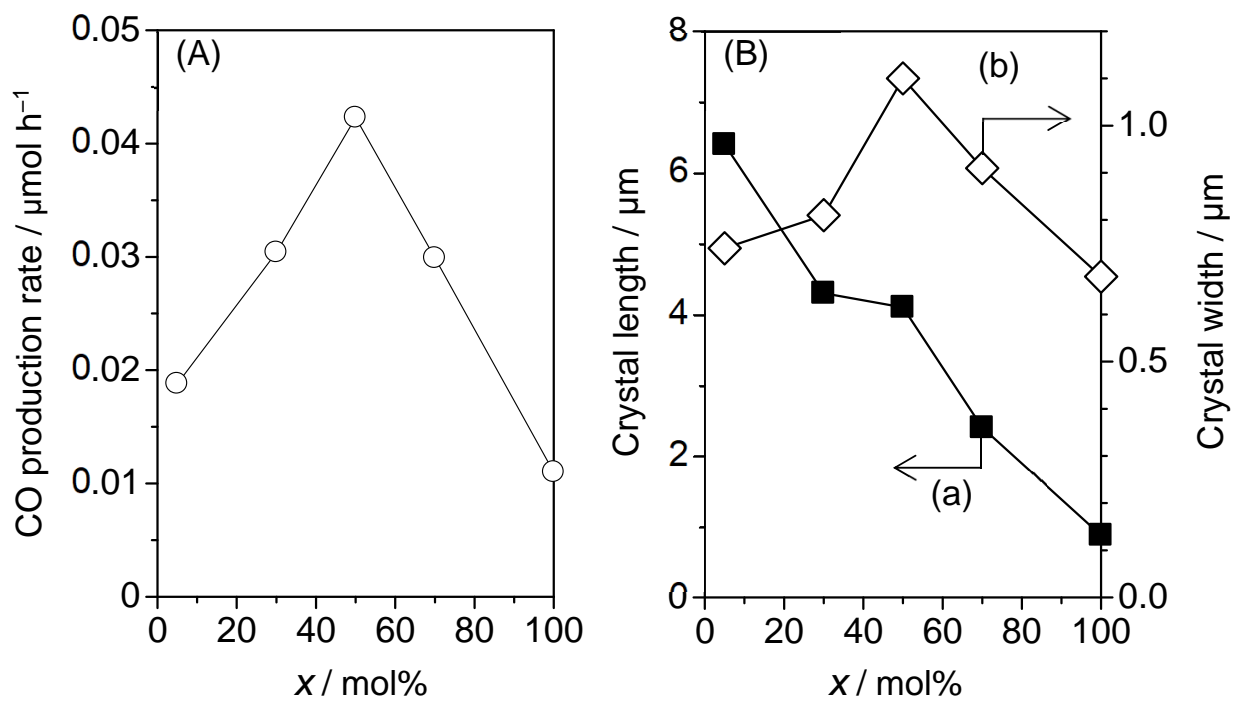

Fig. 8 (A) Variation of the photocatalytic production rate of $\mathrm{CO}$ with the solute concentration $x$ in the preparation of the $\mathrm{Ag} / \mathrm{NTO}(\mathrm{NaCl}, x)$ samples by the flux method in the standard condition, where $x=100$ means the Ag/NTO(SS) sample prepared by the SS method. (B) variation of the average size, length and width, of the rod-like crystals of the $\mathrm{NTO}(\mathrm{NaCl}, \mathrm{x})$ samples with the solute concentration $x$. Values are taken from Tables 1 and 2.

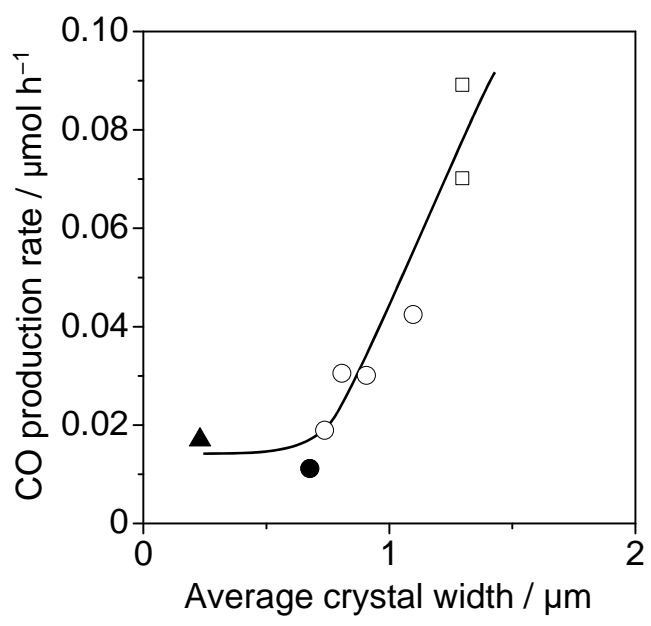

Fig. 9 Effect of the average width of the rod-like crystals or the particle size in the various $\mathrm{Na}_{2} \mathrm{Ti}_{6} \mathrm{O}_{13}$ samples prepared by the flux method by using $\mathrm{NaCl}$ flux with various solute concentrations (open circles), with various cooling rates (open squares), and from anatase as the starting material (closed triangle), and prepared by the solid-state reaction method (closed circle) on the photocatalytic $\mathrm{CO}$ production rate over the corresponding $0.1 \mathrm{wt} \% \mathrm{Ag} / \mathrm{Na}_{2} \mathrm{Ti}_{6} \mathrm{O}_{13}$ samples at $24 \mathrm{~h}$ later from the start of the reaction test. Values are taken from Tables 1 and 2. 

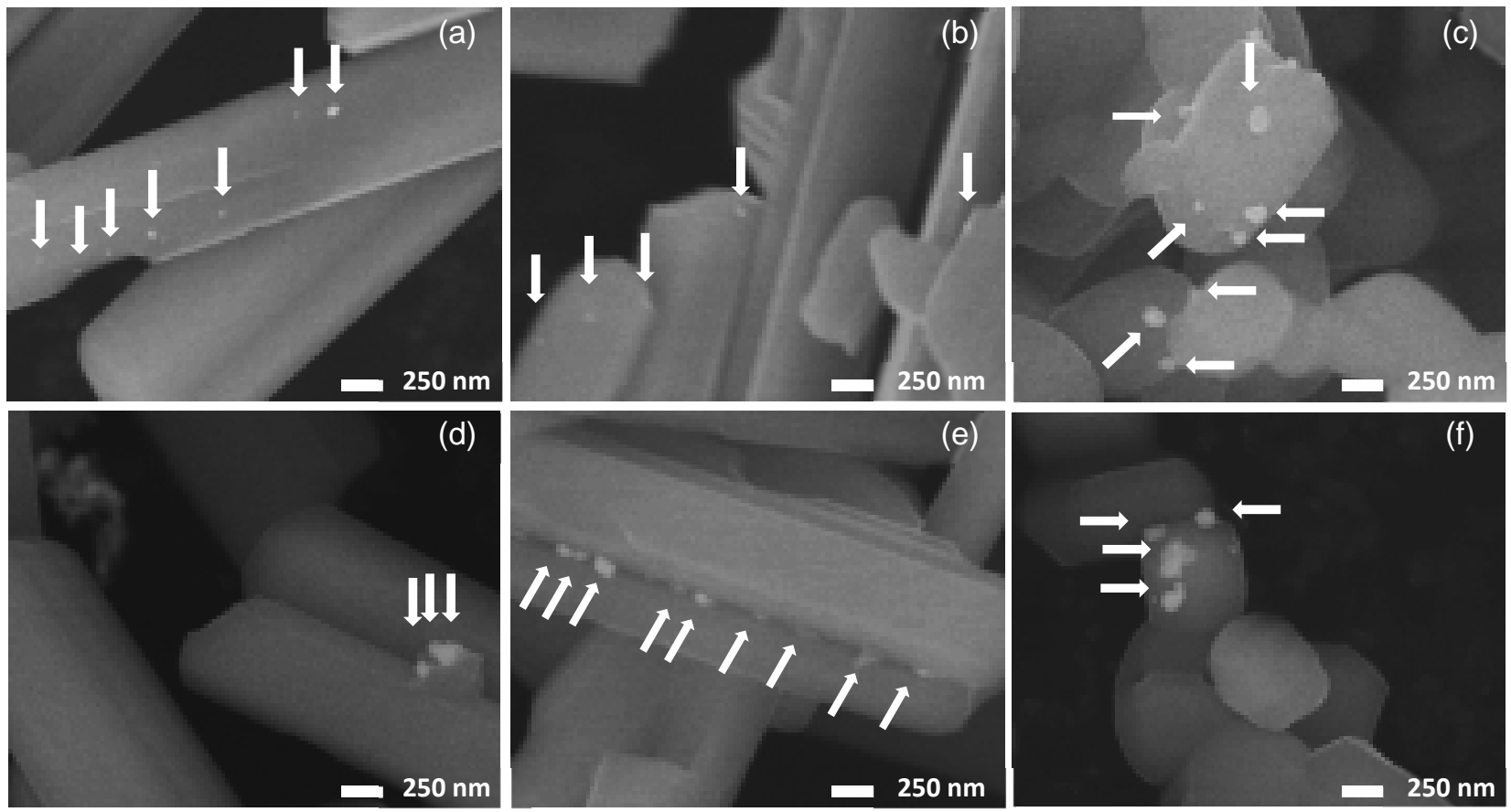

Fig. 10 SEM images of the $A g / N T O(N a C l, 5)$ sample $(a, d)$, the $A g / N T O(N a C l, 50)$ sample $(b, e)$ and the $\mathrm{Ag} /$ the $\mathrm{NTO}(\mathrm{SS})$ sample $(\mathrm{c}, \mathrm{f})$ before $(\mathrm{a}-\mathrm{c})$ and after $(\mathrm{d}-\mathrm{f})$ the use in the photocatalytic $\mathrm{CO}_{2}$ reduction with water. The bright dots indicated by arrows are assignable for the Ag cocatalyst nanoparticles.

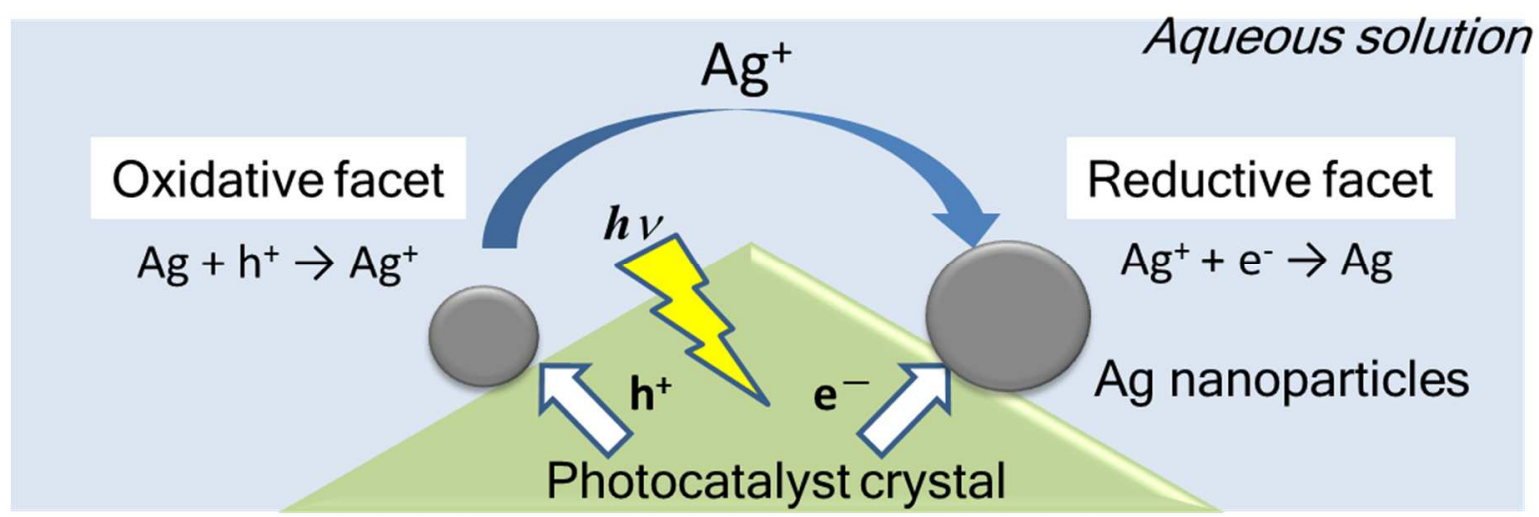

Fig. 11 Proposed mechanism for the growth of the Ag nanoparticles on the photocatalyst during the photocatalytic reaction. 


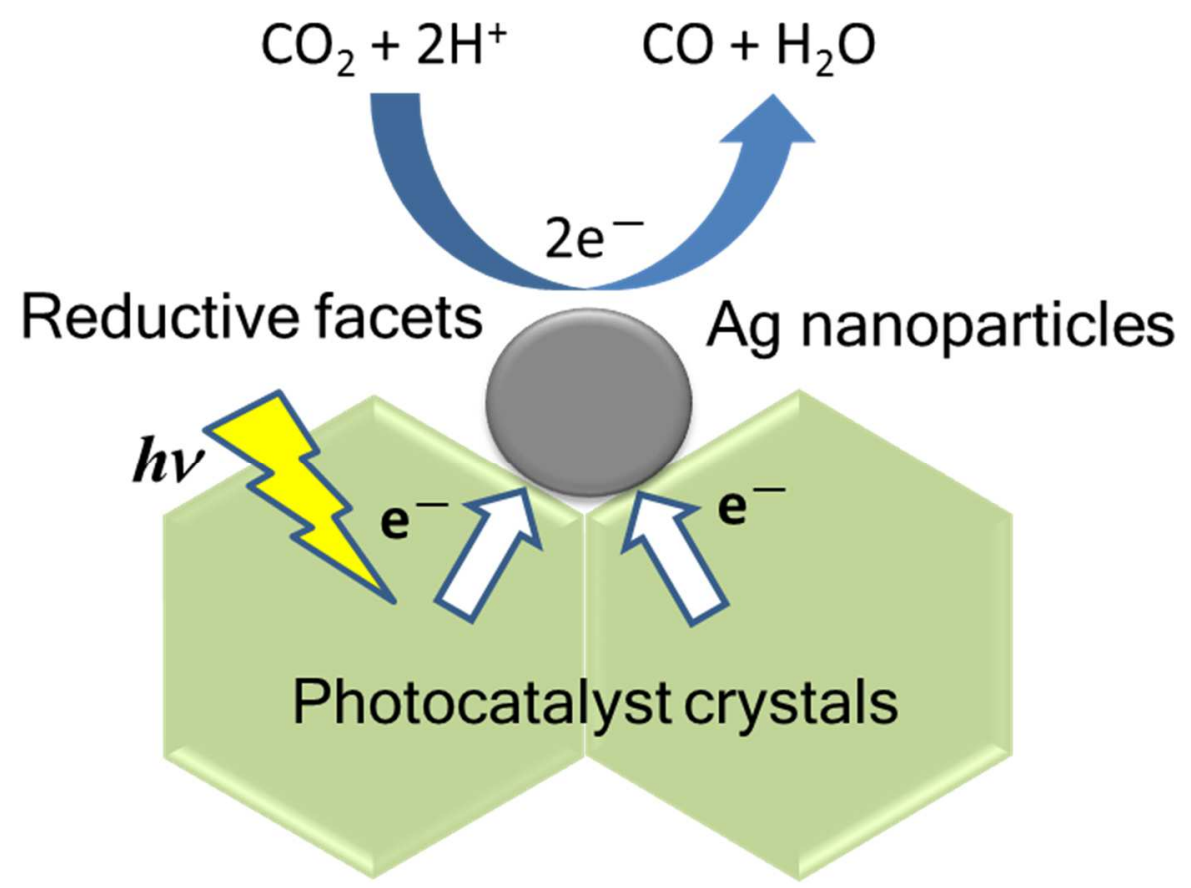

Fig. 12 Photocatalytic reduction of $\mathrm{CO}_{2}$ on the $\mathrm{Ag}$ nanoparticles stabilized on the neighboring reductive facets of the $\mathrm{Na}_{2} \mathrm{Ti}_{6} \mathrm{O}_{13}$ photocatalyst crystals prepared by the flux method. 